Article

\title{
Size variations in foraminifers from the early Permian to the Late Triassic: implications for the Guadalupian-Lopingian and the Permian-Triassic mass extinctions
}

\author{
Yan Feng, Haijun Song*, and David P. G. Bond
}

\begin{abstract}
The final 10 Myr of the Paleozoic saw two of the biggest biological crises in Earth history: the middlePermian extinction (often termed the Guadalupian-Lopingian extinction [GLE]) that was followed 7-8 Myr later by Earth's most catastrophic loss of diversity, the Permian-Triassic mass extinction (PTME). These crises are not only manifest as sharp decreases in biodiversity and-particularly for the PTMEtotal ecosystem collapse, but they also drove major changes in biological morphological characteristics such as the Lilliput effect. The evolution of test size among different clades of foraminifera during these two extinction events has been less studied. We analyzed a global database of foraminiferal test size (volume) including 20,226 specimens in 464 genera, 98 families, and 9 suborders from 632 publications. Our analyses reveal significant reductions in foraminiferal mean test size across the Guadalupian/Lopingian boundary (GLB) and the Permian/Triassic boundary (PTB), from 8.89 to $7.60 \log _{10} \mu \mathrm{m}^{3}\left(\lg \mu \mathrm{m}^{3}\right)$ and from 7.25 to $5.82 \mathrm{lg} \mathrm{mm}^{3}$, respectively. The decline in test size across the GLB is a function of preferential extinction of genera exhibiting gigantism such as fusulinoidean fusulinids. Other clades show little change in size across the GLB. In contrast, all Lopingian suborders in our analysis (Fusulinina, Lagenina, Miliolina, and Textulariina) experienced a significant decrease in test size across the PTB, mainly due to size-biased extinction and within-lineage change. The PTME was clearly a major catastrophe that affected many groups simultaneously, and the GLE was more selective, perhaps hinting at a subtler, less extreme driver than the later PTME.
\end{abstract}

Yan Feng and Haijun Song. State Key Laboratory of Biogeology and Environmental Geology, School of Earth Sciences, China University of Geosciences, Wuhan 430074, China. E-mail: yanf992@gmail.com, haijunsong@ cug.edu.cn.

David P. G. Bond. Department of Geography, Geology and Environment, University of Hull, Hull HU6 7RX,

United Kingdom. E-mail: d.bond@hull.ac.uk

Accepted: 11 August 2020

Data available from the Dryad Digital Repository: https://doi.org/10.5061/dryad.h70rxwdgh

*Corresponding author.

\section{Introduction}

Body size is a key morphological variable that plays a significant role in biology and ecology (Peters 1983; Schmidt-Nielsen 1984; Barbault 1988; Damuth 1991; Cotgreave 1993; Blackburn and Gaston 1994; Brown 1995; Calder 1996; Jablonski et al. 1996; Payne et al. 2009; Petchey and Belgrano 2010). Numerous studies have documented size diminution of individuals in the recovery phases following mass extinction events (Schmidt et al. 2004; Payne 2005; Aberhan et al. 2007; Twitchett 2007; Harries and Knorr 2009). This phenomenon, widely known as the Lilliput effect, was first recognized in several graptolite taxa after relatively small-scale biological crises during the late Silurian (Urbanek 1993). Similar size reductions are seen in several other faunal groups in postextinction strata, for example, Ordovician-Silurian crinoids (Borths and Ausich 2011), terminal Ordovician brachiopods (Huang et al. 2010), early Silurian corals (Kaljo 1996), Late Devonian conodonts (Renaud and Girard 1999) and echinoids (Jeffery and Emlet 2010), and late Guadalupian fusulinoidean fusulinid foraminifers (Payne et al. 2012; Groves and Wang 2013). However, the mechanisms of size change remain controversial. Four biological circumstances were proposed to account for the potential Lilliput effect after the Permian-Triassic mass extinction (PTME): (1) size-based extinction, (2) size-based origination, 
(3) changing relative abundances, and (4) size change within lineages (Payne 2005; see also Twitchett 2007; Song et al. 2011). In addition, the relative proportion of within- and among-lineage processes in changing body size was compared quantitatively by Rego et al. (2012), who concluded that size reduction within lineages rather than size-biased extinction drove the Lilliput effect following the PTME.

The PTME was the most severe biotic crisis of the Phanerozoic, during which the Paleozoic Fauna was replaced by the Modern Fauna (Sepkoski et al. 1981; Bottjer et al. 2008; Erwin 2015). More than $90 \%$ of all marine species and $>70 \%$ of terrestrial species were eliminated during the crisis (Raup 1979; Erwin 1993; Jin et al. 2000; Benton 2003; Song et al. 2013), leading to the "reef gap" (Flügel and Kiessling 2002; Kiessling et al. 2010), a flat latitudinal biodiversity gradient (Song et al. 2020), and a reversed functional pyramid in the Early Triassic oceans (Song et al. 2018). Many kinds of (often synergistic) environmental stresses have been implicated in the crisis, including global warming (Kidder and Worsley 2004; Joachimski et al. 2012; Sun et al. 2012), hypercapnia (Knoll et al. 1996, 2007), oceanic anoxia (Wignall and Hallam 1992; Wignall and Twitchett 1996, 2002; Grice et al. 2005; Kump et al. 2005; Shen et al. 2007; Brennecka et al. 2011; Song et al. 2011; Lau et al. 2016; Penn et al. 2018; Huang et al. 2019), oceanic acidification (Liang 2002; Hinojosa et al. 2012; Clarkson et al. 2015), increased siltation (Algeo and Twitchett 2010) and turbidity (Cao et al. 2019), ozone depletion (Visscher et al. 2004; Beerling et al. 2007; Black et al. 2014; Bond et al. 2017), toxic metal poisoning (Wang 2007; Sanei et al. 2012), and more (Racki and Wignall 2005; Reichow et al. 2009).

The PTME manifests as a sharp decline in biodiversity, the near-total collapse of various ecosystems on land and in the oceans, and morphological changes, including the Lilliput effect, whereby surviving species exhibited decreased body size after extinction events (Urbanek 1993). The Lilliput effect across the Permian/Triassic boundary (PTB) has been recognized in many groups, including foraminifers (Song and Tong 2010; Payne et al. 2011, 2013; Song et al. 2011; Rego et al. 2012; Schaal et al. 2016), conodonts (Luo et al. 2008; Schaal et al. 2016), gastropods (Schubert and Bottjer 1995; Fraiser and Bottjer 2004; Payne 2005; Twitchett 2007; Fraiser et al. 2011; Schaal et al. 2016), brachiopods (He et al. 2007, 2015; McGowan et al. 2009; Zhang et al. 2015, 2016; Schaal et al. 2016; Chen et al. 2019), bivalves (Hayami 1997; Twitchett 2007; Posenato 2009), ostracods (Chu et al. 2015; Schaal et al. 2016), echinoderms (Twitchett et al. 2005), amphibians and reptiles (Benton et al. 2004), and fishes (Mutter and Neuman 2009). Nevertheless, the discovery of larger gastropods from the Early Triassic (Brayard et al. 2010, 2015) has led to some controversy over the true duration of the Lilliput effect.

An earlier Permian mass extinction, across the Guadalupian/Lopingian boundary (GLB) was first recognized by Stanley and Yang (1994) and Jin et al. (1994), who suggested the latest Paleozoic crisis was a "two-stage mass extinction" that initiated with the Guadalupian-Lopingian extinction (GLE). The Capitanian Stage of the Guadalupian Series records various geological phenomena of global scale, including the lowest sea levels of the Phanerozoic (Haq and Schutter 2008) and a low point in the Phanerozoic ocean ${ }^{87} \mathrm{Sr} /{ }^{86} \mathrm{Sr}$ ratio (Veizer et al. 1999; Gradstein et al. 2004; Korte et al. 2006; Kani et al. 2008). The GLE affected a variety of organisms such as corals (Wang and Sugiyama 2000), brachiopods (Shen and Shi 2009), bivalves (Isozaki and Aljinović 2009), bryozoans (Jin et al. 1995), and especially foraminifers - among which the extinction was first recognized (Stanley and Yang 1994; Yang et al. 2004; Ota and Isozaki 2006; Bond et al. 2010a). Payne et al. (2012) illustrated that the test size of fusulinoidean fusulinids in North American and global datasets stabilized in the early-middle Permian and then declined during the late Permian. In addition, Groves and Wang (2013) found that larger fusulinoidean fusulinids such as the Schwagerinidae and Neoschwagerinidaea were key victims of the GLE and that the median volume of fusulinoidean fusulinids exceeded $10 \mathrm{~mm}^{3}$ in the Roadian Stage of the Guadalupian before decreasing to $0.1 \mathrm{~mm}^{3}$ across the GLB. However, it is still not clear whether non-fusulinoidean fusulinids also experienced the Lilliput effect during the GLE. 
Foraminifers, as primary consumers, play a key role in benthic marine ecosystems. We chose to study size variations in foraminifers through both the GLE and PTME as they are not only a key ecological group during those intervals, but they are also abundant and have high preservation potential, making them ideal for study. Previous quantitative analysis of PTB foraminifers from south China has shown that a reduction in foraminiferal test sizes across the boundary was driven by the extinction of large foraminifers as well as size decreases in the survivors and prevalence of smaller newcomers (Song et al. 2011). However, Rego et al. (2012) found that size reduction during the PTME was driven mainly by withinlineage change and the extinction of large genera. In this study, we evaluate size variations in Permian foraminiferal suborders across the GLB and PTB. We compiled a database of foraminifer test size from the early Permian to the Late Triassic in order to evaluate whether the Lilliput effect is a feature of these major extinction events, and whether patterns in test size variation among different foraminiferal suborders are similar during the GLE and PTME.

\section{Data and Methods}

We constructed a global database of foraminifer test sizes from the early Permian to the Late Triassic illustrated in 632 published papers. Our database includes 20,226 individual specimens representing 464 genera, 98 families, and 9 suborders (Table 1). All data are archived at Dryad. We applied the timescale and ages provided in the 2018 IUGS Geological Time Scale (Cohen et al. 2018). The systematic classification of foraminifers has been controversial, and here we follow Tappan and Loeblich (1988), Mikhalevich (2000), Armstrong and Brasier (2004), and Groves et al. (2005). We have performed additional standardization for some controversial and uncertain species (including synonyms) (by H.S.).

Foraminiferal test morphologies are widely variable and include cones, columns, disks, spheres, hemispheres, and ellipsoidal shapes. We use test volume as a proxy for body size to mitigate against biases caused by shape changes over time. Test symmetries were used to
TABLE 1. The total number of foraminiferal specimens, genera, and families recorded in our database at stage level from the early Permian to the Late Triassic.

\begin{tabular}{llrrr}
\hline \hline Epoch & \multicolumn{1}{c}{ Stage } & Specimens & Genera & Families \\
\hline T3 & Rhaetian & 746 & 78 & 36 \\
& Norian & 699 & 63 & 36 \\
& Carnian & 591 & 80 & 33 \\
T2 & Ladanian & 761 & 72 & 35 \\
& Anisian & 2670 & 95 & 32 \\
T1 & Olenekian & 2783 & 43 & 21 \\
& Induan & 178 & 10 & 9 \\
P3 & Changhsingian & 5198 & 131 & 43 \\
& Wuchiapingian & 518 & 72 & 32 \\
P2 & Capitanian & 1077 & 113 & 39 \\
& Wordian & 997 & 91 & 33 \\
& Roadian & 561 & 69 & 33 \\
P1 & Kungurian & 574 & 67 & 27 \\
& Artinskian & 1060 & 97 & 33 \\
& Sakmarian & 988 & 86 & 30 \\
& Asselian & 825 & 77 & 26 \\
\hline
\end{tabular}

calculate test volume from the two measurable axes in thin-sectioned specimens. The logarithmic scale with base 10 of test volume was chosen, because the rate of biological evolution is an inverse power function of time; it is often used for statistical comparison of right-skewed distributions (Gingerich 1983). In addition, the value is reduced on a linear scale after logarithmization, making it easier to compare test sizes across a broad range of sizes (Payne 2005).

The mean, minimum, and maximum sizes, and $95 \%$ confidence intervals of mean size were used to analyze size variations of foraminifers in our database. Here we calculated the test volumes for specimen-level mean values and genus-level mean and maximum values, respectively, because the dataset may include many specimens of some species and few of others, which will affect the overall size distribution.

The mean size $(x)$ is an indicator that reflects trends of all foraminifers in each stage. Because the mean value across all specimens is potentially affected by the relative abundance of different taxa and the illustration frequency in different papers, we use a genus-level metric, which is calculated with the following formula:

$$
x=1 / n * \sum_{i=1}^{n} V i
$$

where $x$ is the genus mean value, $n$ is the total number of foraminifer genera in each stage, and $V_{i}$ is the test size of each foraminifer genus. 
The $95 \%$ confidence interval of the mean size can be calculated using the following equation:

$$
y=t_{\frac{\alpha}{2}} \frac{s}{\sqrt{n}}
$$

where $y$ is the fluctuation range, $t_{\alpha / 2}$ is the $t$-test value of 1- $\alpha$ confidence, $s$ is the standard deviation, and $n$ is the total genus number in each stage. Thus, the $95 \%$ confidence interval is $(x-y, x+y)$, where $x$ is the genus mean value, $x-y$ is the lower $95 \%$ confidence interval, and $x+y$ is the upper $95 \%$ confidence interval. In addition, we chose the $t$-test method to compare the differences in the mean test values of foraminifera between adjacent stages (Table 2), and this analysis is mainly performed using the Statistical Package for the Social Sciences (SPSS).

The frequency of foraminiferal test sizes (in $\log _{10} \mu \mathrm{m}^{3}$, hereafter $\lg \mu \mathrm{m}^{3}$ ) is used to reflect the test size distribution of foraminifers during the Permian-Triassic intervals. Size-distribution histograms and rarefaction curves were generated through the paleontological statistics software package PAST (Hammer et al. 2001).

\section{Results}

Foraminifer Size Distributions.-Figure 1 shows the frequency of test volumes (in $1 g$ $\mu \mathrm{m}^{3}$ ) for all foraminifers in our database during the Permian-Triassic intervals. In general, foraminifers in the early-middle Permian were larger (Fig. 1A), ranging from $4.5 \mathrm{lg} \mu \mathrm{m}^{3}$ to $12.0 \mathrm{lg} \mu \mathrm{m}^{3}$. Late Permian foraminifers were, on average, smaller, with volumes ranging from $4.5 \mathrm{lg} \mu \mathrm{m}^{3}$ to $10.5 \mathrm{lg} \mu \mathrm{m}^{3}$. Figure 1 also reveals the bimodal distribution of test volumes in the early-middle Permian. The smaller volume mode from the early and middle Permian $\left(7.5 \mathrm{lg} \mu \mathrm{m}^{3}\right)$ is the same as that of the late Permian. However, the early and middle Permian larger volume mode is $10.5 \mathrm{lg} \mu \mathrm{m}^{3}, \sim 1000$ times greater in volume than that in the late Permian. This is due to gigantism in the early and middle Permian in groups such as fusulinoidean fusulinids, most of which became extinct during the GLE.

Volume frequencies of foraminifers in the late Permian, Early Triassic, and Late Triassic specimens all conform to the normal distribution. Obviously, the test size of Triassic foraminifers is much smaller than that of Permian foraminifers. Volumes of Early Triassic foraminifers distribute between $4.5 \mathrm{lg} \mu \mathrm{m}^{3}$ and 7.5 $\lg \mu \mathrm{m}^{3}$, and the dominant peak is $6.5-6.8 \mathrm{lg}$ $\mu^{3}$ (Fig. 1C). That is, the volumes of foraminifers in the Early Triassic are the smallest in our study interval. In the Middle and Late Triassic, their size ranged from $5.0 \mathrm{lg} \mu \mathrm{m}^{3}$ to $10.0 \mathrm{lg} \mu \mathrm{m}^{3}$, with foraminifers having volumes from $7.0 \mathrm{lg}$

TABLE 2. Summary statistics of foraminifer genus volumes $\left(\lg \mu \mathrm{m}^{3}\right)$ from the early Permian to the Late Triassic, including maximum, mean, and minimum test volume, $95 \%$ lower and upper confidence intervals (CI), $p$-value and change in mean between adjacent stages. The significance level of $p$-value was 0.05 , e.g., the $p$-value in the Induan is $<0.01$, which shows that $t$-test for mean values between the Changhsingian and Induan is $<0.01$, illustrating the size reduction during this transition is significant $(p<0.05)$.

\begin{tabular}{|c|c|c|c|c|c|c|c|}
\hline Interval & Min. & 95\% Lower CI & Mean value & 95\% Upper CI & Max. & $p$-value & Change in mean \\
\hline Rhaetian & 5.63 & 7.16 & 7.31 & 7.46 & 9.52 & 1 & 0.04 \\
\hline Norian & 6.08 & 7.1 & 7.27 & 7.44 & 10.07 & 1 & 0.04 \\
\hline Carnian & 5.9 & 7.09 & 7.24 & 7.38 & 9.26 & 0.83 & -0.04 \\
\hline Ladanian & 5.33 & 7.11 & 7.27 & 7.43 & 9.26 & 0.33 & 0.16 \\
\hline Anisian & 5.58 & 6.99 & 7.11 & 7.23 & 8.92 & $<0.01$ & 0.59 \\
\hline Olenekian & 5.4 & 6.35 & 6.52 & 6.69 & 7.91 & 0.17 & 0.53 \\
\hline Induan & 5.42 & 5.72 & 5.98 & 6.25 & 6.42 & $<0.01$ & -1.55 \\
\hline Changhsingian & 5.52 & 7.38 & 7.53 & 7.68 & 9.97 & 0.41 & -0.13 \\
\hline Wuchiapingian & 5.7 & 7.45 & 7.67 & 7.88 & 11 & 0.03 & -0.35 \\
\hline Capitanian & 5.71 & 7.78 & 8.02 & 8.25 & 11.71 & $<0.01$ & -0.6 \\
\hline Wordian & 6.49 & 8.33 & 8.62 & 8.9 & 11.28 & 0.08 & 0.3 \\
\hline Roadian & 6.39 & 8.02 & 8.31 & 8.61 & 11.16 & $<0.01$ & -0.56 \\
\hline Kungurian & 5.18 & 8.49 & 8.87 & 9.24 & 11.65 & 0.44 & 0.14 \\
\hline Artinskian & 6.24 & 8.44 & 8.73 & 9.03 & 11.49 & 0.03 & 0.34 \\
\hline Sakmarian & 5.89 & 8.08 & 8.39 & 8.7 & 11.65 & 0.02 & -0.4 \\
\hline Asselian & 5.92 & 8.44 & 8.79 & 9.15 & 11.38 & & \\
\hline
\end{tabular}



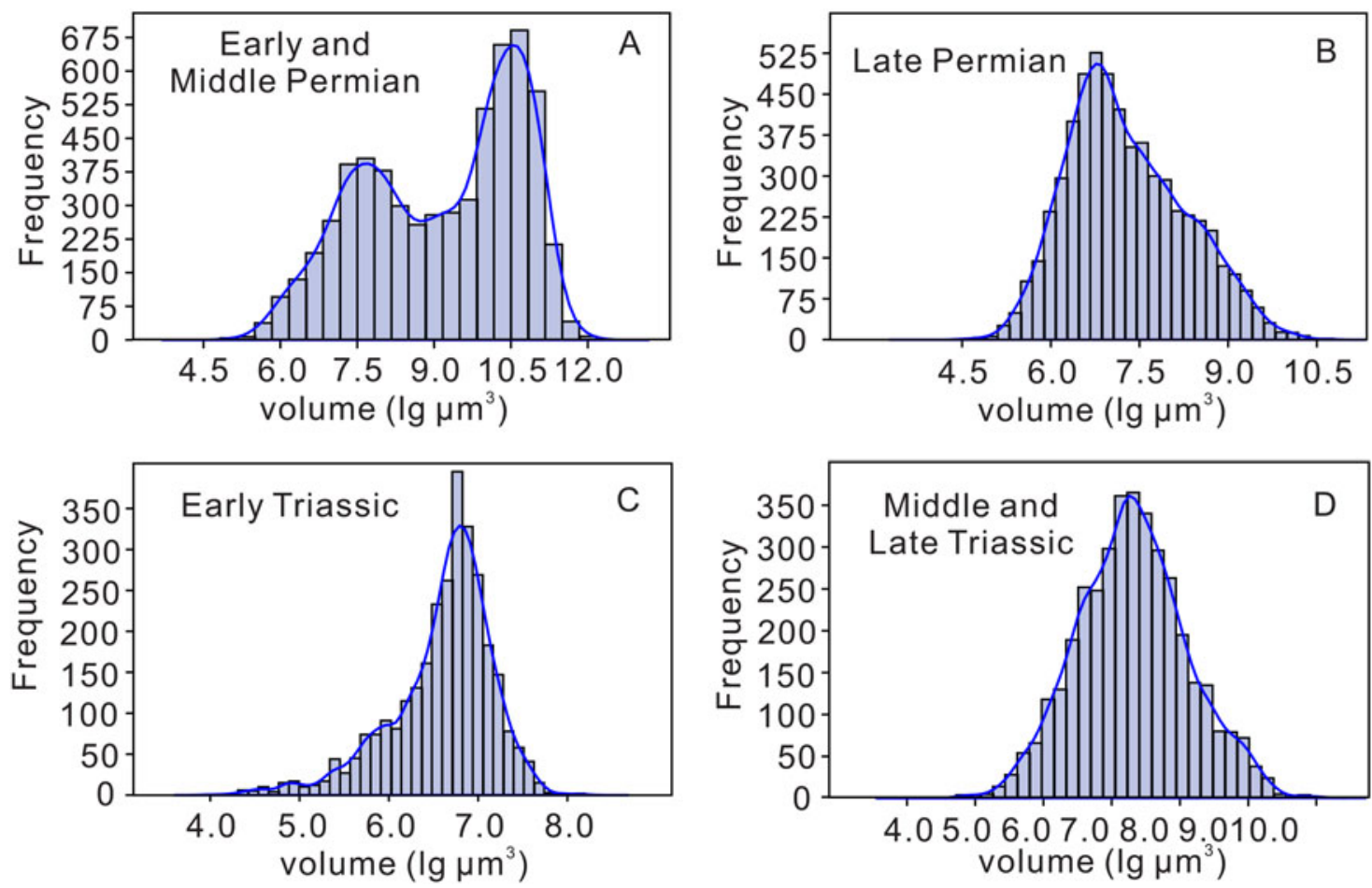

FIGURE 1. Histograms showing volumes of foraminifers (in $\lg \mu \mathrm{m}^{3}$ ) in the database. A, Early and middle Permian; B, late Permian; C, Early Triassic; and D, Middle and Late Triassic.

$\mu \mathrm{m}^{3}$ to $8.0 \mathrm{lg} \mu \mathrm{m}^{3}$ being the most frequently occurring (Fig. 1D). This illustrates that the foraminifers increased in size during the EarlyMiddle Triassic intervals.

Foraminifer Size Variations.-Variations in all foraminifer volumes (in $\lg \mu \mathrm{m}^{3}$ ) during the Permian-Triassic intervals are shown in Figure 2. Figure $2 \mathrm{~A}-\mathrm{C}$ illustrate the test size variations for specimen-level mean values and genuslevel mean and maximum values, respectively. All three figures show similar patterns, in which test size remained stable in the early Permian, and began to decrease from the middle Permian to the Early Triassic, then increase from the Middle Triassic, demonstrating that the total trend of test size variation is not sensitive to the size or taxonomic metric chosen. More interesting, the size change in our data shows trends similar to those identified in Payne et al.'s (2013) study of foraminiferal size evolution that includes almost 25,000 species and subspecies over the past $400 \mathrm{Myr}$. As mentioned earlier, we present subsequent analyses of size changes using the genus mean metric (Fig. 2B). Test size variations can be divided into four distinct intervals:

1. The early and middle Permian interval. The test size was the largest in both maximum $\left(11.16 \mathrm{lg} \mu \mathrm{m}^{3}\right.$ to $\left.11.71 \mathrm{lg} \mu \mathrm{m}^{3}\right)$ and mean $\left(8.02 \mathrm{lg} \mu \mathrm{m}^{3}\right.$ and $\left.8.87 \mathrm{lg} \mu \mathrm{m}^{3}\right)$ sizes throughout the whole study interval. Despite this, foraminifers decreased in mean size from the Asselian (8.79 $\left.\mathrm{lg} \mu \mathrm{m}^{3}\right)$ to the Sakmarian $\left(8.39 \mathrm{lg} \mu \mathrm{m}^{3}\right)$, from the Kungurian $(8.87 \mathrm{lg}$ $\left.\mu \mathrm{m}^{3}\right)$ to the Roadian $\left(8.31 \mathrm{lg} \mu \mathrm{m}^{3}\right)$, and from the Wordian $\left(8.62 \mathrm{lg} \mu \mathrm{m}^{3}\right)$ to the Capitanian $\left(8.02 \mathrm{lg} \mu \mathrm{m}^{3}\right.$ ) (Table 2). These results are similar to those of Payne et al. (2013), who also found that test size in the early and middle Permian was the largest from the Devonian to the Neogene, with the mean volume of foraminifers being approximately $9 \mathrm{lg} \mu^{3}$.

2. The late Permian interval. There is a significant reduction in test size across the GLB. The mean test volume was $8.02 \mathrm{lg} \mu \mathrm{m}^{3}$ in the Capitanian before it decreased to 7.67 


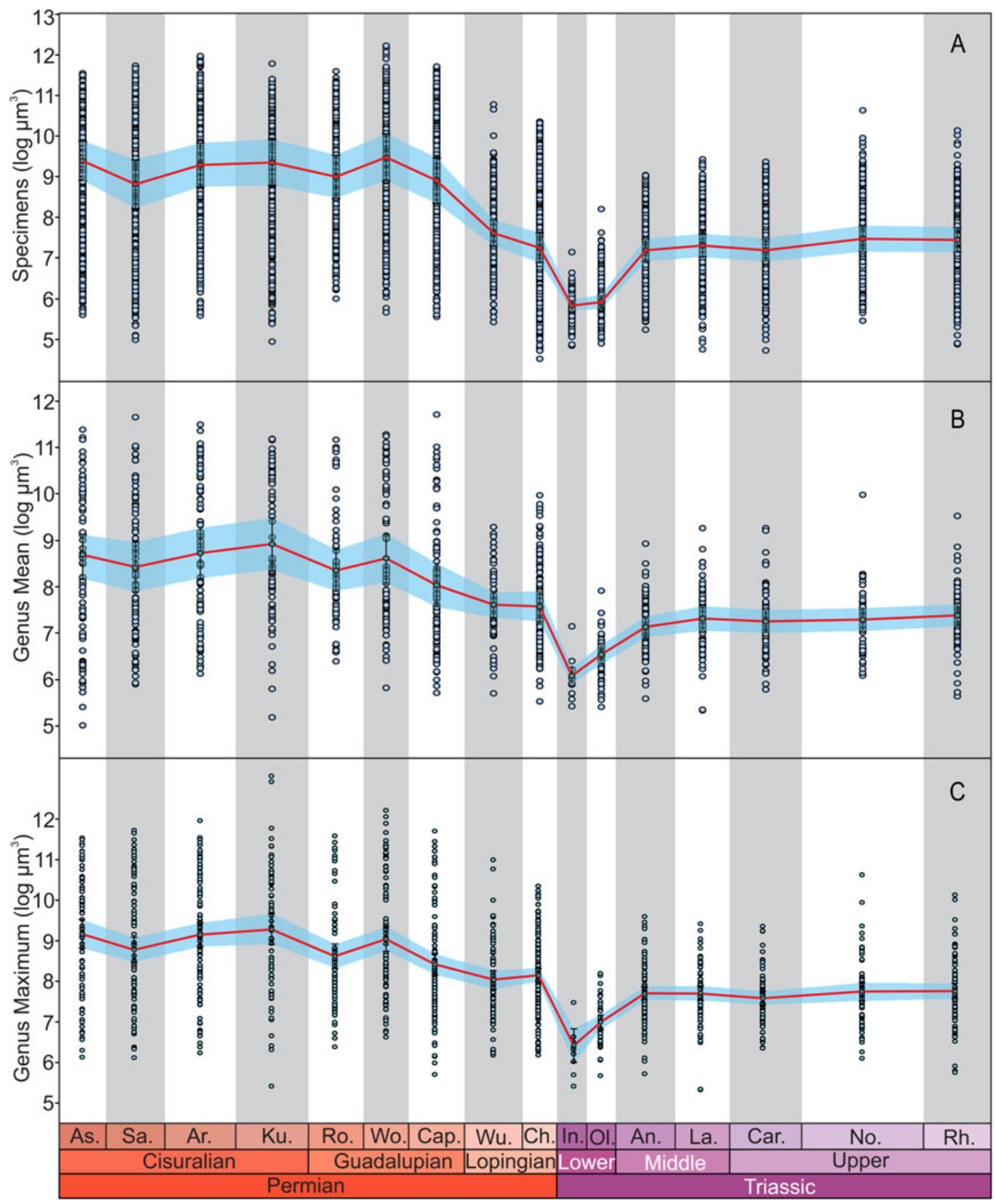

FIGURE 2. Variations in volume (in $\lg \mu \mathrm{m}^{3}$ ) of foraminifers from the beginning of the Permian to the end of the Triassic. A, mean test size variations for all specimens; B, mean test sizes of each genus; C, largest measured specimen of each genus. Abbreviations: As., Asselian; Sa., Sakmarian; Ar., Artinskian; Ku., Kungurian; Ro., Roadian; Wo., Wordian; Cap., Capitanian; Wu., Wuchiapingian; Ch., Changhsingian; In., Induan; Ol., Olenekian; An., Anisian; La., Ladinian; Car., Carnian; No., Norian; Rh., Rhaetian. The middle thick line and shaded areas represent the mean size of the foraminiferal volumes and the $95 \%$ confidence interval, respectively. 
$\lg \mu \mathrm{m}^{3}$ in the Wuchiapingian. Thus, Capitanian foraminifers were about 2.24 times larger than Wuchiapingian examples. In addition, the significant differences of all specimen mean values between adjacent stages have been tested with a $t$-test (Table 2), which clearly demonstrates that the test size declined sharply across the GLB. The mean volumes of foraminifer tests were relatively stable between the Wuchiapingian and the Changhsingian. Payne et al. (2013) observed a similar size reduction between the middle and late Permian, from mean volumes of approximately $9 \mathrm{lg} \mu \mathrm{m}^{3}$ in the Wordian and Capitanian to approximately $8 \mathrm{lg} \mu \mathrm{m}^{3}$ in the Wuchiapingian.

3. The late Permian to Early Triassic interval, including the transition across the PTB, sees the most significant size reduction in our entire database. The mean test volume was $7.53 \mathrm{lg} \mu \mathrm{m}^{3}$ for Changhsingian specimens, but this value dropped to $5.98 \mathrm{lg}$ $\mu \mathrm{m}^{3}$ in the Induan. The $t$-test for specimen mean values indicates that the size decrease during this period was significant $(p<$ 0.001 ). In addition, the change in mean during this period is the largest $\left(-1.55 \lg \mu \mathrm{m}^{3}\right)$ in the early Permian to Late Triassic interval (Table 2). Maximum and mean test volumes fluctuated slightly across the Induan/Olenekian boundary. The maximum and mean test sizes in Olenekian genera were $7.91 \mathrm{lg}$ $\mu \mathrm{m}^{3}$ and $6.52 \mathrm{lg} \mu \mathrm{m}^{3}$, respectively. This is consistent with the significant mean size decrease across the PTB reported by Payne et al. (2013), who recorded mean test sizes in the Induan of approximately $6.8 \mathrm{lg} \mu^{3}$.

4. The Middle and Late Triassic interval. Foraminifers increased their maximum and mean sizes dramatically during the Olenekian and Anisian (the maximum and mean test volumes were $8.92 \mathrm{lg} \mu \mathrm{m}^{3}$ and $7.11 \mathrm{lg} \mu \mathrm{m}^{3}$, respectively). Overall, mean test volumes then remained relatively stable from the Anisian onward. These volume-change trends are identical to those of Payne et al. (2013), who noted that the mean size increased between the Early Triassic and the Middle Triassic and remained relatively stable in the Middle and Late Triassic $\left(7.1 \lg \mu \mathrm{m}^{3}\right)$.

Size Variations in Foraminifer Suborders.-We analyzed volume variations in nine foraminiferal suborders (Fig. 3). Four out of nine suborders survived during the Permian-Triassic intervals: Fusulinina, Textulariina, Miliolina, and Lagenina. In the Permian, the volumes of Fusulinina were largest in the early-middle

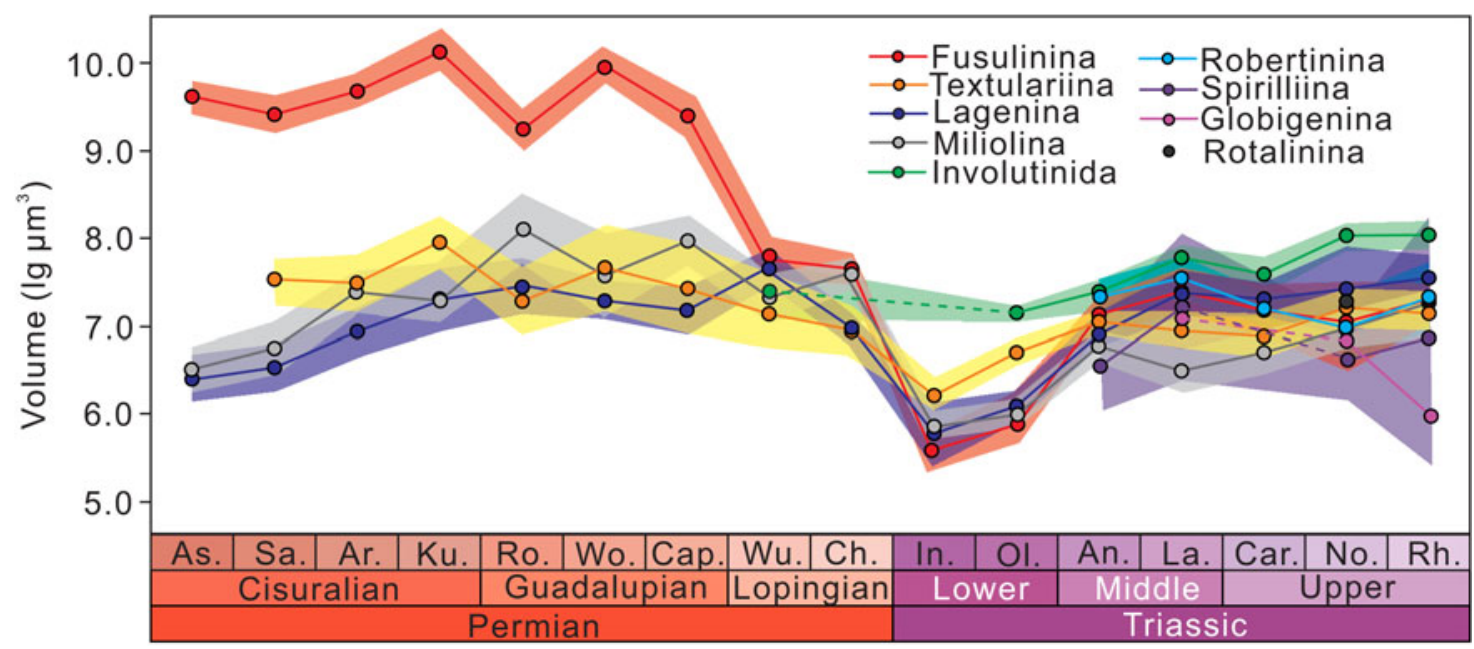

FIGURE 3. Trends in mean value of nine suborders of foraminifers from the beginning of the Permian through the end of the Triassic. Abbreviations are defined in Fig. 2. Each point represents the mean volume of specimens in a suborder within each stage. Solid lines represent continuous occurrences through time, dotted lines represent discontinuous occurrences, and shaded areas represent the $95 \%$ confidence intervals. 

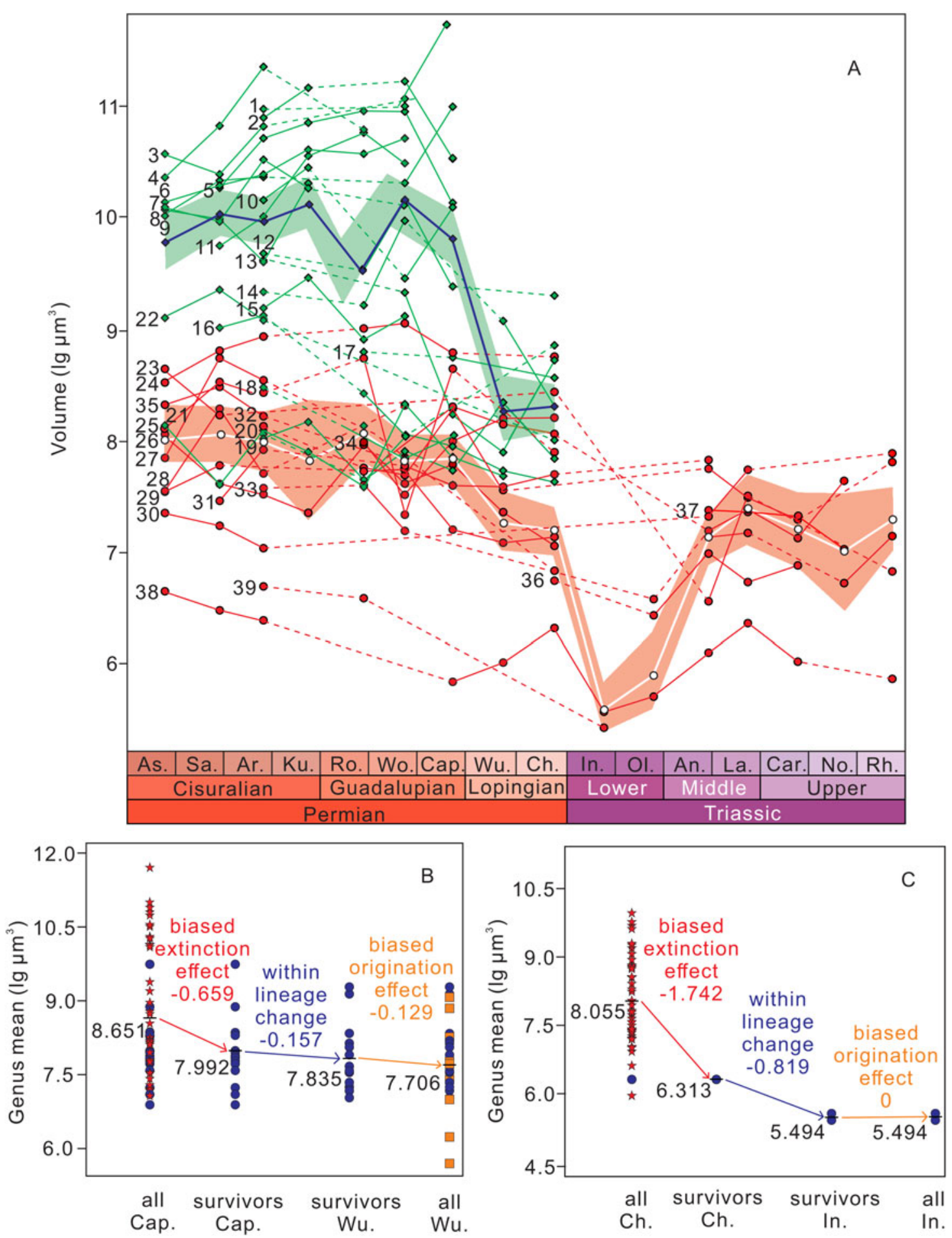
FIGURE 4. Test size variations of Fusulinina from the beginning of the Permian through to the end of the Triassic. A, mean value trends of each genus. B,C, genus-level analysis of three component values (size-biased extinction, size-biased origination, and within-lineage evolution) across the GLB and PTB, respectively. Abbreviations are defined in Fig. 2. In A, the two thick solid lines in the middle represent the mean volume of fusulinoidean fusulinids and non-fusulinoidean fusulinids, respectively. The shaded areas represent the 95\% confidence intervals. Fusulinoidea: 1, Verbeekina; 2, Polydiexodina; 3, Codonofusiella; 4, Pseudoschwagerina; 5, Parafusulina; 6, Pseudofusulina; 7, Rugosofusulina; 8, Quasifusulina; 9, Schwagerina; 10, Sumatrina; 11, Monodiexodina; 12, Sphaerulina; 13, Nankinella; 14, Staffella; 15, Yangchienia; 16, Pseudoendothyra; 17, Minojapanella; 18, Rauserella; 19, Reichelina; 20, Dunbarula; 21, Schubertella; 22, Cribrogenerina. Non-fusulinoidean fusulinids: 23, Polytaxis; 24, Climacammina; 25, Deckerella; 26, Globivalvulina; 27, Bradyina; 28, Palaeotextularia; 29, Endothyra; 30, Endothyranella; 31, Neoendothyra; 32, Dagmarita; 33, Endoteba; 34, Abadehella; 35, Tetrataxis; 36, Neotuberitina; 37, Endotriadella; 38, Earlandia; 39, Diplosphaerina. In B and C, stars denote extinction victims, circles denote genera that survived across the GLB and

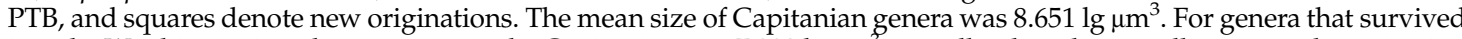
into the Wuchiapingian, the mean size in the Capitanian was $7.992 \mathrm{lg} \mu \mathrm{m}^{3}$ - smaller than the overall mean, so the extinction was size biased. The variation in mean size due to this size-biased extinction was $7.992-8.651=-0.659 \mathrm{lg} \mu \mathrm{m}^{3}$. Of the surviving genera, their mean size in the Wuchiapingian was $7.835 \mathrm{lg} \mu \mathrm{m}^{3}$, and so the estimated change in size due to withingenus evolution is $7.835-7.992=-0.157 \mathrm{lg} \mu \mathrm{m}^{3}$. The mean value of all Wuchiapingian Fusulinina was $7.706 \mathrm{lg}^{3} \mathrm{~m}^{3}$. Thus the change in mean size due to this size-biased origination was $7.706-7.835=-0.129 \mathrm{lg} \mu \mathrm{m}^{3}$. This calculation method follows that of Rego et al. (2012).

Permian $\left(>9.0 \mathrm{lg} \mu \mathrm{m}^{3}\right)$, before they decreased significantly from the middle to late Permian. Thus, their mean test volume decreased from $9.40 \mathrm{lg} \mu \mathrm{m}^{3}$ in the Capitanian to $7.76 \mathrm{lg} \mu \mathrm{m}^{3}$ in the Wuchiapingian. The mean volume of Fusulinina tests in the Capitanian was 43.6 times larger than that in the Wuchiapingian. The mean values of Textulariina, Lagenina, and Miliolina were similar in the early-middle Permian, ranging from $5.93 \mathrm{lg} \mu \mathrm{m}^{3}$ to $8.12 \mathrm{lg} \mu \mathrm{m}^{3}$. All four suborders experienced a sharp reduction in mean volumes across the PTB (Fig. 3). For example, the mean volume of Fusulinina declined from $7.65 \mathrm{lg} \mu \mathrm{m}^{3}$ in the Changhsingian to $5.72 \mathrm{lg} \mu \mathrm{m}^{3}$ in the Induan. Thus, the mean volume of Fusulinina in the Changhsingian was 85.1 times greater than that in the Induan. The test size of these four suborders recovered between the Induan and Olenekian and increased significantly from the Early to Middle Triassic. In the Middle-Late Triassic, the volume of the nine extant suborders remained

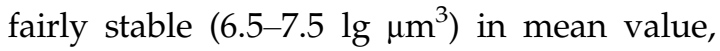
with the exception of the Globigenina, whose test volumes fell from $6.87 \mathrm{lg} \mu \mathrm{m}^{3}$ in the Norian to $6.02 \mathrm{lg} \mu \mathrm{m}^{3}$ in the Rhaetian. However, the $t$-test was used to compare the mean value between the Norian and Rhaetian, suggesting that this size variation was not significant during this period $(p=0.518)$.

Fusulinina.-To evaluate the different patterns in size variations experienced by the Fusulinina in contrast to Textulariina, Lagenina, and Miliolina (e.g., the major reductions in Fusulinina volumes across the GLB and
PTB), we examined trends at the genus level within this suborder (Fig. 4A). During the early to middle Permian, the maximum volumes of Fusulinina exceeded $10.0 \mathrm{lg} \mu \mathrm{m}^{3}$, and the volumes of some genera even reached $11.0 \mathrm{lg} \mu \mathrm{m}^{3}$ (e.g., Verbeekina, Polydiexodina, and Pseudoschwagerina; Fig. 4A). During the late Permian, the maximum volumes of Fusulinina did not exceed $9.5 \mathrm{lg} \mu \mathrm{m}^{3}$. Many fusulinoidean fusulinid genera died out during the GLE, the victims of which included Verbeekina, Polydiexodina, and Codonofusiella. In the Early Triassic, the test size of Fusulinina dropped to $<7.0 \mathrm{lg}$ $\mu \mathrm{m}^{3}$ (Table 3), a function of the extinction of all remaining fusulinoidean fusulinids during the PTME. Some Permian genera (e.g., Polytaxis and Endoteba) that are absent in Early Triassic strata reappeared in the Middle-Late Triassic, so-called Lazarus taxa (Jablonski 1986). These Lazarus taxa led to an increase (Fig. 4A), but their tests were still smaller on average than they had been during the Permian.

Figure 4A shows variations in volumes among fusulinoidean fusulinids and nonfusulinoidean fusulinids. Fusulinina with more than three occurrences in our database are represented. Our data set includes 39 genera in 16 families, of which fusulinoidean fusulinids make up 22 genera and nonfusulinoidean fusulinids make up 16 genera. Fusulinoidean fusulinids range in volume from $7.27 \mathrm{lg} \mu \mathrm{m}^{3}$ to $11.71 \mathrm{lg} \mu \mathrm{m}^{3}$. Nine genera survived the GLE: Sphaerulina, Nankinella, Pseudoendothyra, Staffella, Minojapanella, Rauserella, 
TABLE 3. Summary of volumes of tests $\left(\lg \mu \mathrm{m}^{3}\right)$ belonging to Fusulinina from the early Permian to the Late Triassic, including fusulinoidean fusulinids and non-fusulinoidean fusulinids. CI, confidence interval.

\begin{tabular}{|c|c|c|c|c|c|c|c|c|c|}
\hline \multirow[b]{2}{*}{$\underline{\text { Stage }}$} & \multicolumn{3}{|c|}{ Fusulinina } & \multicolumn{3}{|c|}{ Fusulinoidean fusulinids } & \multicolumn{3}{|c|}{ Non-fusulinoidean fusulinids } \\
\hline & $\begin{array}{c}95 \% \\
\text { Lower CI }\end{array}$ & $\begin{array}{l}\text { Mean } \\
\text { value }\end{array}$ & $\begin{array}{c}95 \% \\
\text { Upper CI }\end{array}$ & $\begin{array}{c}95 \% \\
\text { Lower CI }\end{array}$ & $\begin{array}{l}\text { Mean } \\
\text { value }\end{array}$ & $\begin{array}{c}95 \% \\
\text { Upper CI }\end{array}$ & $\begin{array}{c}95 \% \\
\text { Lower CI }\end{array}$ & $\begin{array}{l}\text { Mean } \\
\text { value }\end{array}$ & $\begin{array}{c}95 \% \\
\text { Upper CI }\end{array}$ \\
\hline Rhaetian & 7.41 & 7.26 & 7.11 & & & & 7.16 & 7.3 & 7.44 \\
\hline Norian & 7.4 & 7.01 & 6.61 & & & & 6.61 & 7.01 & 7.4 \\
\hline Carnian & 7.39 & 7.19 & 6.98 & & & & 6.98 & 7.19 & 7.39 \\
\hline Ladinian & 7.55 & 7.4 & 7.24 & & & & 7.24 & 7.4 & 7.55 \\
\hline Anisian & 7.21 & 7.13 & 7.06 & & & & 7.06 & 7.13 & 7.2 \\
\hline Olenekian & 6.14 & 5.89 & 5.64 & & & & 5.64 & 5.89 & 6.14 \\
\hline Induan & 5.69 & 5.57 & 5.44 & & & & 5.44 & 5.57 & 5.69 \\
\hline Changhsingian & 7.71 & 7.65 & 7.59 & 8.25 & 8.31 & 8.38 & 7.16 & 7.21 & 7.27 \\
\hline Wuchiapingian & 7.91 & 7.76 & 7.62 & 8.12 & 8.29 & 8.46 & 7.14 & 7.27 & 7.41 \\
\hline Capitanian & 9.5 & 9.4 & 9.29 & 9.74 & 9.84 & 9.94 & 7.74 & 7.84 & 7.94 \\
\hline Wordian & 10.06 & 9.97 & 9.88 & 10.11 & 10.19 & 10.27 & 7.71 & 7.82 & 7.93 \\
\hline Roadian & 9.36 & 9.23 & 9.1 & 9.4 & 9.55 & 9.69 & 7.94 & 8.09 & 8.24 \\
\hline Kungurian & 10.22 & 10.12 & 10.03 & 10.05 & 10.14 & 10.23 & 7.29 & 7.83 & 8.36 \\
\hline Artinskian & 9.76 & 9.68 & 9.6 & 9.91 & 9.99 & 10.06 & 7.82 & 7.99 & 8.16 \\
\hline Sakmarian & 9.5 & 9.41 & 9.32 & 9.99 & 10.05 & 10.12 & 7.95 & 8.06 & 8.17 \\
\hline Asselian & 9.7 & 9.61 & 9.53 & 9.7 & 9.8 & 9.9 & 7.81 & 8.01 & 8.2 \\
\hline
\end{tabular}

Dunbarula, Schubertella, and Reichelina. A volume reduction across the GLB resulted in mean volumes of fusulinoidean fusulinids decreasing from $9.84 \mathrm{lg} \mu \mathrm{m}^{3}$ in the Capitanian to $8.29 \mathrm{lg} \mu \mathrm{m}^{3}$ in the Wuchiapingian. All fusulinoidean fusulinids became extinct during the PTME. The test size of non-fusulinoidean fusulinids was smaller $\left(<9.34 \mathrm{lg} \mu \mathrm{m}^{3}\right)$, and their volumes were only modestly affected by the GLE. The larger genera Climacammina, Abadehella, Cribrogenerina, Deckerella, and Globivalvulina died out during the PTME, resulting in a further volume reduction across the PTB.

Figure 4B,C quantifies three modes of miniaturization of the Fusulinina across the GLB and PTB, and our methods follow those of Rego et al. (2012). Figure 4B shows that the mean size of 49 Fusulinina genera was 8.651 $\lg \mu \mathrm{m}^{3}$ in the Capitanian. Of these 49 genera, 33 died out across the GLB, and 16 existed into the Wuchiapingian. The mean value for the 16 survivors in the Capitanian was $7.99 \mathrm{lg}$ $\mu \mathrm{m}^{3}$, which illustrates that larger genera were more likely to go extinct. This suggests that the test size change may have been due to sizebiased extinction and the size change was 7.99 $-8.65=-0.66 \mathrm{lg} \mu \mathrm{m}^{3}$. The mean size of the 16 surviving genera was $7.84 \mathrm{lg} \mu \mathrm{m}^{3}$ in the Wuchiapingian, and thus the size change due to within-genus trends is $7.84-7.99=$ $-0.15 \mathrm{lg} \mu \mathrm{m}^{3}$. In the Wuchiapingian, 11 genera originated, and the mean value of all Wuchiapingian Fusulinina was $7.71 \mathrm{lg} \mu \mathrm{m}^{3}$. Thus the size change due to size-biased origination is $7.71-7.84=-0.13 \mathrm{lg} \mu \mathrm{m}^{3}$. Therefore, three modes can be considered the cause of size change across the GLE: size-biased extinction $\left(-0.66 \mathrm{lg} \mu \mathrm{m}^{3}\right)$, within-lineage change $(-0.15$ $\left.\lg \mu \mathrm{m}^{3}\right)$, and size-biased origination $(-0.13$ $\left.\lg \mu \mathrm{m}^{3}\right)$. All Changhsingian Fusulinina went extinct during the PTME, with the exception of Earlandia and Diplosphaerina (Fig. 4A). Figure $4 \mathrm{C}$ shows that the mean size of all Changhsingian Fusulinina was $8.06 \mathrm{lg} \mu \mathrm{m}^{3}$. The mean size of the surviving genera was $6.31 \mathrm{lg} \mu \mathrm{m}^{3}$ in the Changhsingian (Fig. 4A), and so the size reduction due to the size-biased extinction effect is $6.31-8.06=-1.75 \mathrm{lg} \mu \mathrm{m}^{3}$. Two Fusulinina genera in the Induan are recorded in our data with a mean size of $5.49 \mathrm{lg} \mu \mathrm{m}^{3}$, meaning that the size decrease due to within-genus change is $5.49-6.31=-0.82 \mathrm{lg} \mu \mathrm{m}^{3}$. Because no new genera of Fusulinina appeared in the Induan, the size change due to size-biased origination is 0. In summary, as for Fusulinina, size reduction following the GLE and PTME was driven mainly by the extinction of larger genera. Size change within surviving genera and the origination of new small genera could also have resulted in further size reduction.

Lagenina.-The mean test volume of Permian Lagenina fluctuated over a narrow 

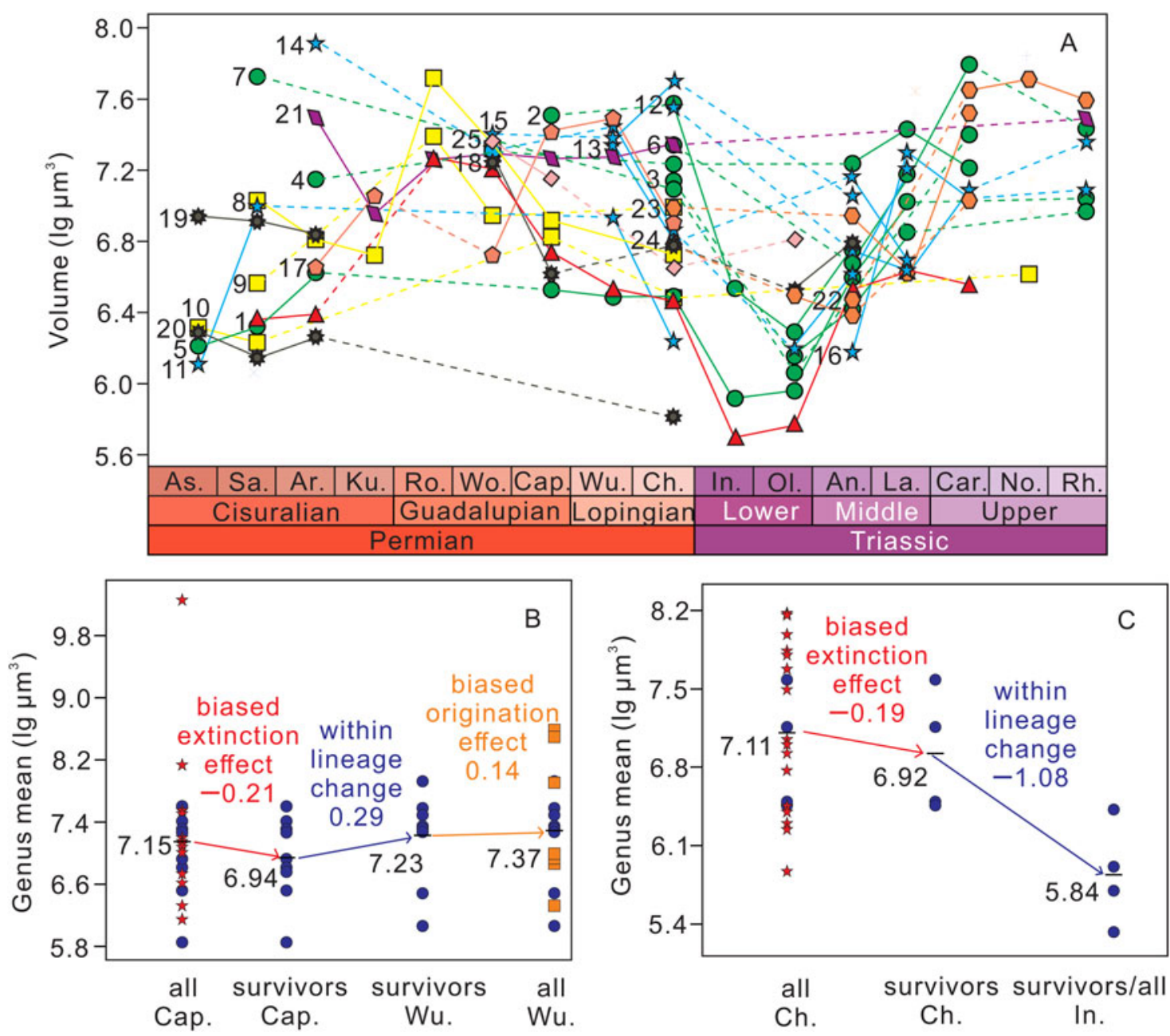

FIGURE 5. Test size variations of Lagenina from the beginning of the Permian through to the end of the Triassic (25 genera in 8 families). A, Mean value trends of each genus. B,C, Genus-level analysis of three component values (size-biased extinction, size-biased origination, and within-lineage evolution) across the Guadalupian/Lopingian boundary and the Permian/Triassic boundary, respectively. Abbreviations are defined in Fig. 2. The calculation methods for B and C are listed in Fig. 4. Only genera occurring in three or more stages are included in this figure. Families are represented by different shapes. 1, Nodosinelloides; 2, Lingulina; 3, Dentalina; 4, Pseudoglandulina; 5, Nodosaria; 6, Pseudonodosaria; 7, Nodosinella; 8, Geinitzina; 9, Vervilleina; 10, Polarisella; 11, Pachyphloides; 12, Austrocolomia; 13, Protonodosaria; 14, Frondina; 15, Cryptoseptida; 16, Grillina; 17, Robuloides; 18, Rectostipulina; 19, Syzrania; 20, Tezaquina; 21, Pachyphloia; 22, Astacolus; 23, Lenticulina; 24, Marginulina; 25, Ichthyofrondina.

range (from $6.40 \mathrm{lg} \mu \mathrm{m}^{3}$ to $7.65 \mathrm{lg} \mu \mathrm{m}^{3}$; Fig. 3). The $t$-test for specimen means shows that the size reduction across the PTB was significant $(p=0.001$; Fig. 5A). Only genera recorded in three or more stages are included in our analysis; thus Figure 5 includes 25 genera and 8 families. The genera Nodosinelloides, Lingulina, and Nodosaria exhibit size reduction across the PTB (e.g., the volume of Lingulina fell from $7.58 \mathrm{lg} \mu \mathrm{m}^{3}$ in the Changhsingian to $6.42 \mathrm{lg}$ $\mu \mathrm{m}^{3}$ in the Induan). The mean test volume of the Lagenina began to increase from the Induan

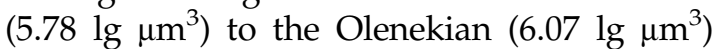
(Table 4). More significant volume increases occurred between the Olenekian and the Anisian $\left(6.91 \mathrm{lg} \mu \mathrm{m}^{3}\right)$ (Table 4). Some new genera originated during the Anisian, such as Grillina and Astacolus. During the Middle-Late Triassic, some Lazarus genera also returned, such as Dentalina and Protonodosaria, and the range of 
TABLE 4. Summary of test volumes $\left(\lg \mu \mathrm{m}^{3}\right)$ from the early Permian to the Late Triassic in the suborders Fusulinina, Lagenina, Miliolina, and Textulariina.

\begin{tabular}{lcccc}
\hline \hline & Fusulinina & Lagenina & Miliolina & Textulariina \\
\hline Rhaetian & 7.26 & 7.55 & 7.14 & 7.17 \\
Norian & 7.01 & 7.39 & 6.97 & 7.21 \\
Carnian & 7.19 & 7.31 & 6.7 & 6.9 \\
Ladinian & 7.4 & 7.38 & 6.5 & 6.96 \\
Anisian & 7.13 & 6.91 & 6.78 & 7.07 \\
Olenekian & 5.89 & 6.07 & 5.99 & 6.69 \\
Induan & 5.57 & 5.78 & 5.87 & 6.22 \\
Changhsingian & 7.65 & 6.94 & 7.59 & 6.96 \\
Wuchiapingian & 7.76 & 7.65 & 7.33 & 7.13 \\
Capitanian & 9.4 & 7.17 & 7.97 & 7.43 \\
Wordian & 9.97 & 7.29 & 7.84 & 7.66 \\
Roadian & 9.23 & 7.46 & 8.31 & 7.95 \\
Kungurian & 10.12 & 7.31 & 6.18 & 7.49 \\
Artinskian & 9.68 & 6.94 & 7.39 & 7.54 \\
Sakmarian & 9.41 & 6.54 & 6.75 & \\
Asselian & 9.61 & 6.4 & 6.51 & \\
\hline
\end{tabular}

mean test volumes was $6.91-7.55 \mathrm{lg} \mu \mathrm{m}^{3}$, similar to the volumes attained during the Permian (6.40-7.45 $\left.\lg \mu \mathrm{m}^{3}\right)$.

We further quantified three modes of size variation across the two extinction events (Fig. 5B,C). The mean size of all Capitanian Lagenina genera was $7.15 \mathrm{lg} \mu \mathrm{m}^{3}$, and of these, 9 genera survived to the Wuchiapingian. The survivors' mean value in the Capitanian was $6.94 \mathrm{lg} \mu \mathrm{m}^{3}$. Thus the size change due to size-biased extinction effect is $6.94-7.15=$ $-0.21 \mathrm{lg} \mu \mathrm{m}^{3}$, while in the Wuchiapingian, the mean size of the surviving genera was $7.23 \mathrm{lg}$ $\mu \mathrm{m}^{3}$, indicating that size change due to withinlineage change is $7.23-6.94=0.29 \mathrm{lg} \mu \mathrm{m}^{3}$. The mean size of all Wuchiapingian Lagenina was $7.37 \mathrm{lg} \mu \mathrm{m}^{3}$. Thus, the size change due to the biased-origination effect is $7.37-7.23=$ $0.14 \mathrm{lg} \mu \mathrm{m}^{3}$. In summary, the size change across the GLB is $-0.21+0.29+0.14=0.22 \mathrm{lg} \mu \mathrm{m}^{3}$, which confirms that there is no size decrease during this interval. Figure 5C shows that the mean size of 20 Lagenina genera was $7.11 \mathrm{lg}$ $\mu \mathrm{m}^{3}$ in the Changhsingian, of these, 16 genera went extinct in the PTME. In the Changhsingian, the remaining 4 survivors' mean value was $6.92 \mathrm{lg} \mu \mathrm{m}^{3}$. Thus the size reduction due to the size-biased extinction effect is $6.92-7.11=-0.19 \mathrm{lg} \mu \mathrm{m}^{3}$. In the Induan, the survivors' mean value was $5.84 \mathrm{lg} \mu \mathrm{m}^{3}$, so the size change due to within-lineage change is $5.84-6.92=-1.08 \mathrm{lg} \mu \mathrm{m}^{3}$. In our data, no new Lagenina genera originated in the Induan, so the size change due to the biased origination effect is 0 . In summary, the size reduction in the PTME was mainly due to within-lineage change. The extinction of large genera could also have resulted in further size reduction.

Miliolina.-Figure 3 shows the mean size change of Miliolina specimens during the Permian-Triassic intervals. The mean size increased between the early and middle Permian. The $t$-test for the means of all specimens suggests that this size change was not significant $(p=1.000)$ in the middle Permian. A more significant volume reduction occurred across the PTB, probably as a result of the extinction of several genera or an adaptation to smaller sizes in order to survive. For example, Eolasiodiscus, Lasiodiscus, Multidiscus, and Neodiscus became extinct, while Rectocornuspira reduced its test volume during the PTME (Fig. 6A). A modest size increase occurred from the Induan to the Olenekian, and then the Miliolina increased in volume more significantly between the Early and Middle Triassic. This is mainly due to some new originations (Planiinvoluta and Ophthalmidium) and the reappearance of some Lazarus genera (Agathammina). The range of test volumes for the Miliolina reached $5.61-7.63 \mathrm{lg} \mu \mathrm{m}^{3}$ in the Middle to Late Triassic, still smaller than the test volumes of the Permian. Figure 6B,C shows three patterns of test size change in the GLE and PTME. There were 25 Miliolina genera in the Capitanian when mean size was $7.46 \mathrm{lg} \mu \mathrm{m}^{3}$. Of these, 10 genera survived to the Wuchiapingian, and the mean size of 

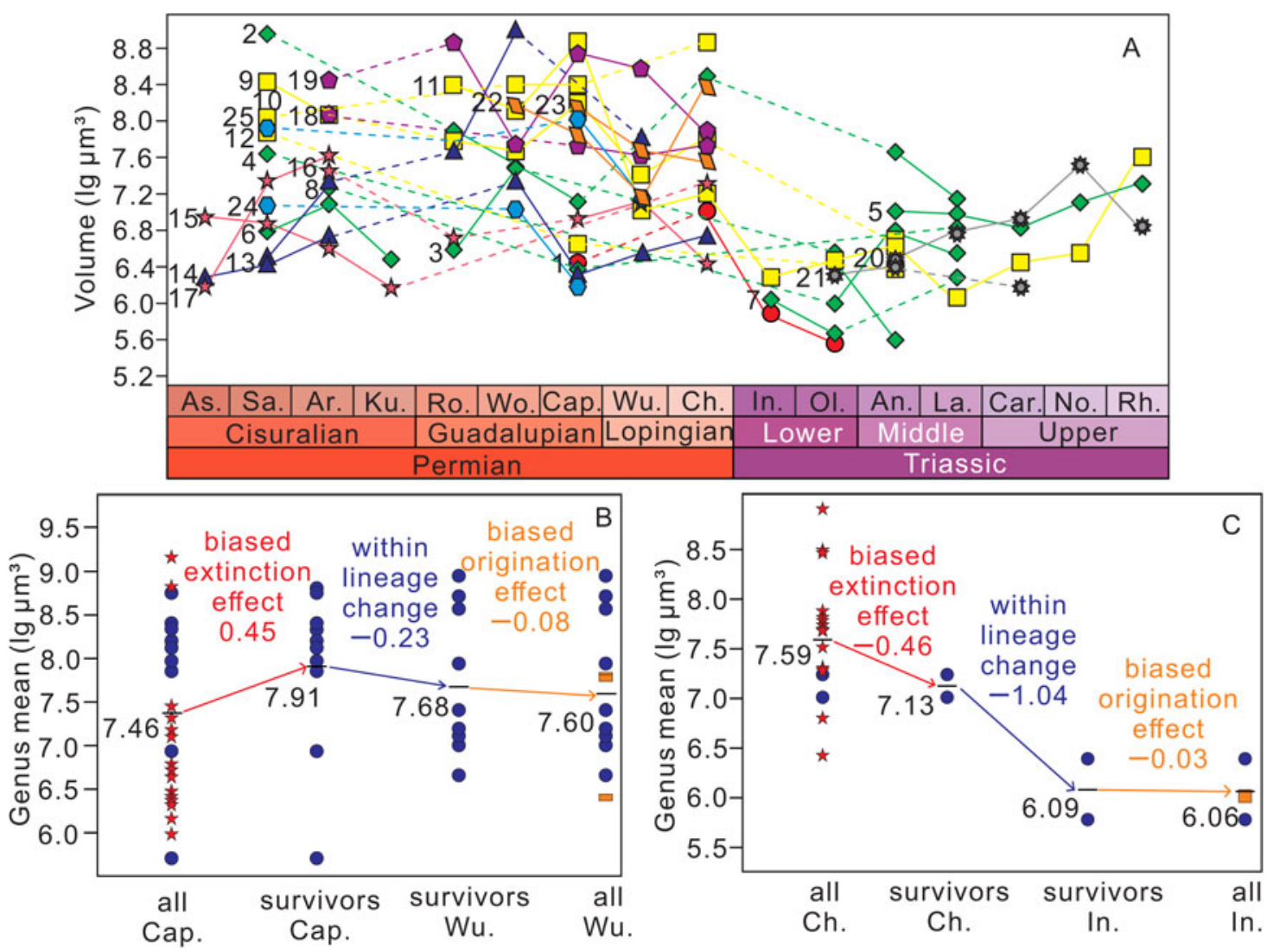

FIgURE 6. Test size variations of Miliolina from the beginning of the Permian through to the end of the Triassic ( 25 genera in 7 families). A, Mean value trends of each genus. B,C, Genus-level analysis of three component values (size-biased extinction, size-biased origination, and within-lineage evolution) across the Guadalupian/Lopingian boundary and the Permian/Triassic boundary, respectively. Abbreviations are defined in Fig. 2. The calculation methods for B and C are listed in Fig. 4. Only genera occurring in three or more stages are included in this figure. Families are represented by different shapes. 1, Rectocornuspira; 2, Calcitornella; 3, Cornuspira; 4, Meandrospira; 5, Planiinvoluta; 6, Calcivertella; 7, Cyclogyra; 8 , Streblospira; 9, Agathammina; 10, Hemigordiopsis; 11, Hemigordius; 12, Orthovertella; 13, Neohemigordius; 14, Pseudovidalina; 15, Eolasiodiscus; 16, Lasiodiscus; 17, Xingshandiscus; 18, Multidiscus; 19, Neodiscus; 20, Ophthalmidium; 21, Gsollbergella; 22, Baisalina; 23, Nikitinella; 24, Pseudoglomospira; 25, Palaeonubecularia.

these genera in the Capitanian was $7.91 \lg \mu \mathrm{m}^{3}$. It is interesting that some small Miliolina genera disappeared across the GLB. Thus the size change due to extinction effect is $7.91-7.46=$ $0.45 \mathrm{lg} \mu \mathrm{m}^{3}$. In the Wuchiapingian, the mean size of the survivors was $7.68 \mathrm{lg} \mu \mathrm{m}^{3}$, and thus the size change in the survivors is $7.68-$ $7.91=-0.23 \mathrm{lg} \mathrm{m}^{3}$. The mean size of all Wuchiapingian Miliolina, including newly originating genera, was $7.60 \mathrm{lg} \mu \mathrm{m}^{3}$. Therefore, the size change due to biased origination effect is $7.60-7.68=-0.08 \mathrm{lg} \mu \mathrm{m}^{3}$. In summary, the size change across the GLB is $0.45+(-0.23)+$ $(-0.08)=0.14 \mathrm{lg} \mu \mathrm{m}^{3}$, which also illustrates that the size change during this interval was not particularly significant at the species level. In contrast, size change is apparent across the PTME. The mean size of all Changhsingian Miliolina was $7.59 \mathrm{lg} \mu \mathrm{m}^{3}$, of these, only 2 genera survived to the Induan. The survivors' mean value was $7.13 \mathrm{lg} \mu \mathrm{m}^{3}$ in the Changhsingian. Thus, the size change due to size-biased extinction is $7.13-7.59=-0.46 \mathrm{lg} \mu \mathrm{m}^{3}$. In the Induan, the survivors' mean value was $6.09 \mathrm{lg} \mu \mathrm{m}^{3}$; thus the size change due to withinlineage change is $6.09-7.13=-1.04 \mathrm{lg} \mu \mathrm{m}^{3}$. The mean size of all Miliolina in the Induan was $6.06 \mathrm{lg} \mu \mathrm{m}^{3}$. Therefore, the size change due to the biased origination effect is $6.06-$ $6.09=-0.03 \mathrm{lg} \mu \mathrm{m}^{3}$. The size decrease across 


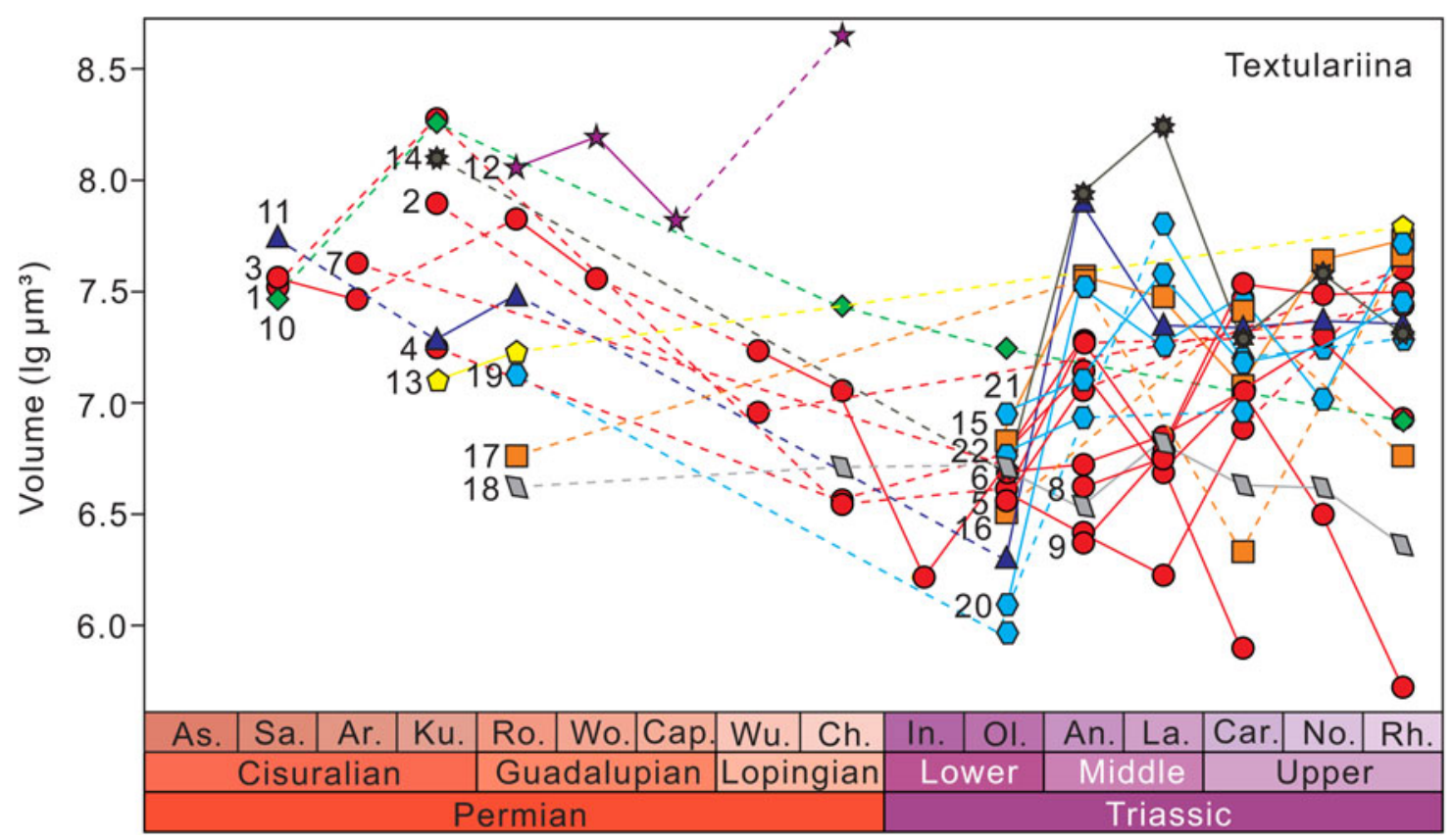

FiguRE 7. Genus trends of Textulariina volumes from the beginning of the Permian through to the end of the Triassic. Abbreviations are defined in Fig. 2. Families are represented by different shapes. 1, Ammodiscus; 2, Ammovertella; 3, Glomospira; 4, Glomospirella; 5, Pilammina; 6, Rectoglomospira; 7, Tolypammina; 8, Turriglomina; 9, Turritellella; 10, Hyperammina; 11, Ammobaculites; 12, Kamurana; 13, Spiroplectammina; 14, Reophax; 15, Palaeolituonella; 16, Bigenerina; 17, Textularia; 18, Trochammina; 19, Verneuilinoides; 20, Duotaxis; 21, Gaudryina; 22, Gaudryinella.

the PTB is $-0.46+(-1.04)+(-0.03)=-1.53 \mathrm{lg}$ $\mu \mathrm{m}^{3}$. In summary, there was no significant size change in the Miliolina across the GLE, whereas the decrease across the PTME is obvious and was mainly due to size-biased extinction and within-lineage reduction.

Textulariina.-Figure 3 reveals that the mean test volumes of Permian Textulariina were stable. Size variations were minor, with test volumes ranging from $6.96 \mathrm{lg} \mu \mathrm{m}^{3}$ to $7.95 \mathrm{lg}$ $\mu \mathrm{m}^{3}$. A notable volume reduction occurred across the PTB, with test volumes falling from $6.96 \mathrm{lg} \mu \mathrm{m}^{3}$ in the Changhsingian to $6.22 \mathrm{lg}$ $\mu \mathrm{m}^{3}$ in the Induan. Textulariina began to increase in volume from the Induan to the Olenekian, driven primarily by the origination of genera such as Rectoglomospira and Palaeolituonella that increased in size significantly in the Olenekian. Figure 7 illustrates the genus trends in test volumes among the Textulariina and reveals that the range of mean test sizes among Textulariina was 6.22-7.21 $\mathrm{lg} \mu \mathrm{m}^{3}$ in the Triassic, as large as they had been during the Permian.

\section{Discussion}

Sufficiency of Specimens.-Sampling bias clearly has the potential to influence the range of foraminifer test volumes during each stage in our study. To evaluate the sampling sufficiency and demonstrate that our data are complete to the extent that they are representative of the volumes of all individuals in each stage, we conducted a rarefaction analysis (Fig. 8) that was first developed by Sanders (1968). Rarefaction is used to compare the diversity of two samples based on similar sample sizes and can also be used to show whether the sample size is adequate (Raup 1975). Figure 8 shows that further collecting is unlikely to add new genera, as each curve is approaching an asymptote.

Size Variations across the GLB.-The size reduction across the GLB has already been reported by previous studies (Isozaki et al. 2007; Bond et al. 2010b; Groves and Wang 2013). Our study confirms that the reduction in test volumes across the GLB was a function 


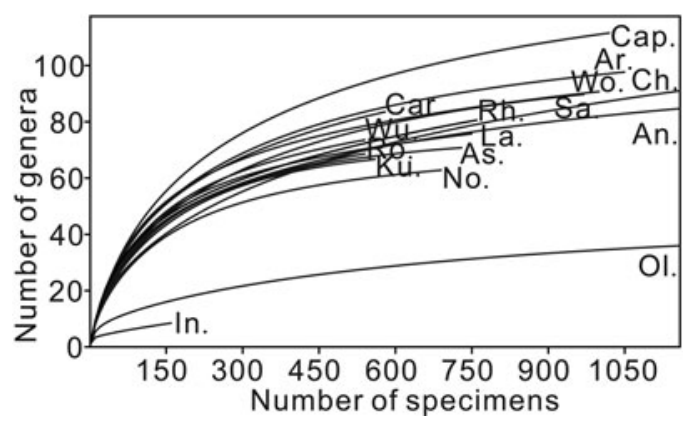

FIGURE 8. Rarefaction curves (specimens vs. genera) of foraminifer test volumes for each stage. Abbreviations are defined in Fig. 2.

of the extinction of larger fusulinoidean fusulinids during the GLE. The mean test volume of foraminifers decreased from $9.40 \mathrm{lg} \mu \mathrm{m}^{3}$ in the Capitanian to $7.76 \lg \mathrm{m}^{3}$ in the Wuchiapingian (Fig. 3). Of these, the mean volume of fusulinoidean fusulinids was $9.84 \mathrm{lg} \mu \mathrm{m}^{3}$ in the Capitanian and $8.29 \mathrm{lg}^{\mathrm{g}} \mathrm{m}^{3}$ in the Wuchiapingian (Fig. 4). In addition, specimens belonging to the fusulinoidean fusulinids accounted for $53 \%$ of all foraminifers in the Capitanian, but only $19 \%$ in the Wuchiapingian. Nonfusulinoidean fusulinids, Miliolina, and Textulariina also saw a reduction in test volume between the Capitanian and Wuchiapingian, but only slightly. In contrast, Lagenina experienced a small increase in mean test volumes, from $7.17 \mathrm{lg} \mu \mathrm{m}^{3}$ in the Capitanian to $7.65 \mathrm{lg}$ $\mu \mathrm{m}^{3}$ in the Wuchiapingian.

The Lilliput effect across the GLB can still be attributed to multiple drivers. Figure $4 \mathrm{~B}$ has quantified three modes of Fusulinina size reduction in the GLE, that is, the selective extinction of large genera, within-lineage change, and the origination of new small genera, following the methods of Rego et al. (2012). As discussed earlier, size decreased $8.651-7.992=0.945 \mathrm{lg} \mu \mathrm{m}^{3}$ from the Capitanian to the Wuchiapingian. Of the three modes of Fusulinina size reduction, size change owing to the size-biased extinction effect is $-0.659 \mathrm{lg} \mu \mathrm{m}^{3}$, which means that the selective extinction of large genera was an important contributor to the size reduction across the GLE. However, it is also known that body size changes with environmental shift (Atkinson 1994; Smith et al. 1995). The miniaturization experienced by the Fusulinina might be linked to one or more of the following causes.

1. Emeishan Traps volcanism in southern China. The GLE has close temporal coincidence with the initial period of Emeishan volcanism (Wignall et al. 2009; Bond et al. 2010a). Large-scale volcanism can potentially destroy atmospheric ozone, resulting in excessive exposure to ultraviolet $\mathrm{B}$ among shallow-water taxa, with detrimental effects for photosynthetic taxa. Thus, keriothecal-walled fusulinaceans such as members of the Schwagerinidae and Neoschwagerinidae suffered preferential losses during the GLE, perhaps as a result of photosymbiont loss (Ross 1972; Ota and Isozaki 2006; Bond et al. 2010a). On the other hand, Zhang and Payne (2012) illustrated that species in the keriothecal-walled families Verbeekidae, Neoschwagerinidae, and Schwagerinidae are much larger than members of the Schubertellidae, Staffellidae, and Ozawainellidae. However, smaller foraminifers are generally more likely to survive the environmental changes driven by a volcanism event because of their shorter generation times and comparatively lower energy needs (Song et al. 2011). In addition, Emeishan volcanogenic (and thermogenic) $\mathrm{CO}_{2}$ (Retallack 2002, 2005; Bond et al. 2010b; Bond and Grasby 2017) could have dissolved into seawater, resulting in its decreased $\mathrm{pH}$ value in the ocean, that is, oceanic acidification (Bond et al. 2010b), which would reduce calcification and growth rate of benthic calcareous foraminifers (Kuroyanagi et al. 2009; Song et al. 2011). In short, the cessation of photosynthesis, lowered productivity, and acidification are all potential effects of Emeishan volcanism that might have driven the extinction of larger keriothecal-walled and calcareous foraminifers. Our study shows that the disappearance of larger fusulinoidean fusulinids and the miniaturization of survivors coincided with the emplacement of the Emeishan Traps (Figs. 4, 9), suggesting a causal link.

2. Oceanic anoxia, recorded locally across the GLB (Isozaki 1997; Wignall et al. 2010; Chen et al. 2011; Bond et al. 2015, 2020), is an oft-cited cause of species extinction in marine settings (Hallam and Wignall 1997; Courtillot and Renne 2003; Bond et al. 2010a, 2015), and 


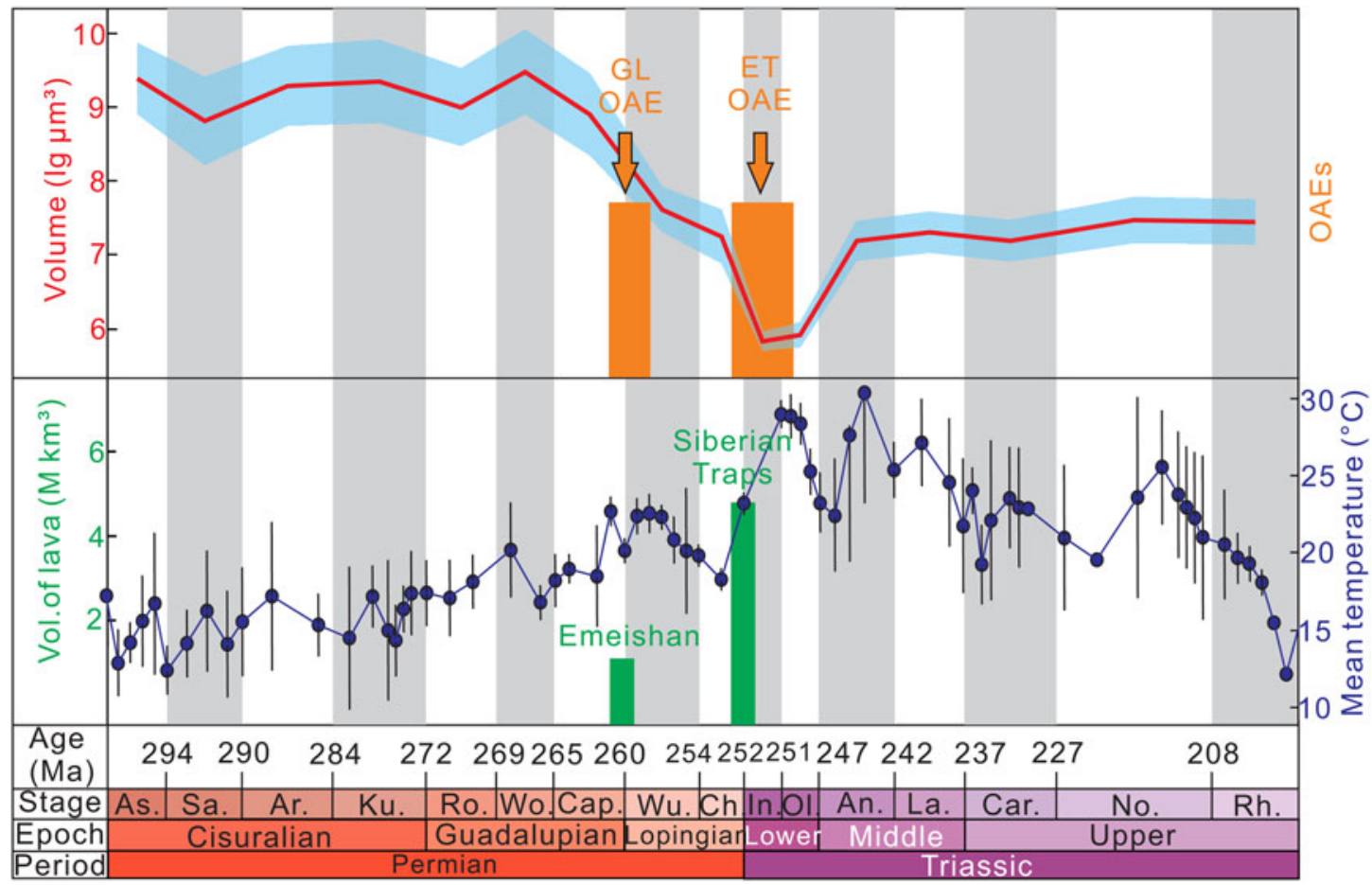

FIGURE 9. Summary of foraminifer test volumes (from this study), sea-surface temperatures, volcanic events, and oceanic anoxic events (OAEs) during the early Permian to the Late Triassic interval. The bars below represent the estimated original volumes of flood basalt provinces (Wignall 2001; Courtillot and Renne 2003; Bond et al. 2010b). The long curve and short vertical lines below show global mean temperatures and $95 \%$ confidence intervals in ${ }^{\circ} \mathrm{C}$, respectively (Song et al. 2019). The boxes above indicate OAEs (Isozaki 1997; Wignall and Twitchett 2002; Clapham et al. 2009; Detian et al. 2013 ; Song et al. 2019). Abbreviations are defined in Fig. 2. Additionally, ET, Early Triassic; GL, Guadalupian-Lopingian. The curve and shading represent mean test size of the foraminiferal specimens and the $95 \%$ confidence interval, respectively.

oxygen deficiency is a potential driver of the Lilliput effect in foraminifers during the GLE. Most benthic invertebrates experience difficulties in secreting and retaining calcareous tests in oxygen-deprived environments (Rhoads and Morse 1971). Therefore, larger calcareous foraminifers such as Fusulinina were more likely to die out in an anoxic-driven GLE scenario. On the other hand, foraminifers are very sensitive to variations in dissolved oxygen. Basov (1979) discovered that benthic foraminifers living in reduced oxygen settings tend to be smaller, usually with thinner and transparent walls and without sculpture.

3. Climate warming. It has been reported that a phase of global warming initiated near the GLB (Isozaki et al. 2007; Chen et al. 2011, 2013). Temperature is one of the most influential and pervasive environmental factors recognized as affecting body size
(Angilletta et al. 2004; Hunt and Roy 2006). The "temperature-size rule" invokes a negative correlation between temperature and body size (Atkinson and Sibly 1997; Hunt and Roy 2006; Atkinson et al. 2019), which is exhibited by many animals, including foraminifers (Lewis and Jenkins 1969; Bjørklund 1976; Schmidt et al. 2006). First, oxygen solubility is lower in warmer waters, which would influence body size, as discussed earlier. Second, temperature can affect body size by changing the growth rate and the frequency of reproduction. For example, lower temperatures generally result in a slower growth rate and lower fecundity but a larger size at maturity (Angilletta et al. 2004). Therefore, the predicted $\sim 4^{\circ} \mathrm{C}$ warming across the GLB (Song et al. 2019) is also a potential driver of the Lilliput effect in foraminifers during the GLE (Fig. 9). 
Size Variations across the PTB.-The Lilliput effect has been observed in many organisms during the PTME (see references in the "Introduction"). More interestingly, the size change during the Permian-Triassic intervals shown in Figure $2 \mathrm{~A}$ is in accordance with Payne et al.'s (2013) study of nearly 25,000 foraminiferal species and subspecies over the past 400 Myr, that is, the mean test size in the early and middle Permian was the largest at about $9 \mathrm{lg} \mu \mathrm{m}^{3}$. Mean size began to decrease from the middle Permian, and by the Induan, the mean test size was the smallest at about $6.8 \mathrm{lg}$ $\mu \mathrm{m}^{3}$. Sizes then increased from the Induan to the Olenekian and became stable in the Middle and Late Triassic $\left(7.2 \mathrm{lg} \mu \mathrm{m}^{3}\right)$.

In our study, a size reduction is seen in all Lopingian foraminifers (i.e., Fusulinina, Lagenina, Miliolina, and Textulariina) across the PTB. In addition, all remaining fusulinoidean fusulinids became extinct during the PTME. Some larger non-fusulinoidean fusulinids also died out, such as Climacammina (Fig. 4), or had to reduce their volume (e.g., Glomospira; Fig. 7). Some new Early Triassic genera were very small and then became larger (e.g., Ophthalmidium; Fig. 6), which may be a function of the "Brobdingnag effect" introduced by Atkinson et al. (2019).

With regard to the timing and cause of size reductions more generally, $\mathrm{He}$ et al. (2007) found that the Lilliput effect of brachiopod species appeared before the PTME, possibly as a result of regression, increased inflow of terrestrial material, and reduced productivity. Twitchett (2007) reported the Lilliput effect in both body and trace fossils in the aftermath of the PTME, driven by four factors (size-biased extinction, the new appearance of many small genera, the transitory disappearance of larger genera, and within-lineage size decreases) with origins in anoxia and food shortages. Luo et al. (2008) demonstrated that the conodonts Hindeodus-Isarcicella underwent four distinct phases of size decrease across the PTB at Meishan, and two phases of size decrease in the earliest Triassic at Shangsi, possibly triggered by eustatic sea-level changes, hypoxic events, and carbon isotope fluctuations. Huttenlocker (2014) evaluated temporal distributions of therocephalian and cynodont therapsid body size during the middle Permian-Triassic intervals and found that the mean size in basal skull length of therocephalians decreased across both the GLB and PTB, probably in response to the ecological removal of large-bodied species. Chu et al. (2015) described miniaturization in freshwater ostracods $\left(0.4 \lg \mu \mathrm{m}^{3}\right)$ during the PTME and invoked several stresses, consisting of global warming, hypoxia, and increased input of terrestrial materials following acid rain and wildfires. We consider that the causes of the Lilliput effect during the PTME can be summarized as follows:

1. Oceanic anoxia. Previous studies have demonstrated the development of superanoxia during the PTB interval (Wignall and Twitchett 2002; Grice et al. 2005; Bond and Wignall 2010; Brennecka et al. 2011; Lau et al. 2016; Li et al. 2018), and such harmful conditions persisted in many areas throughout almost the whole Early Triassic, an interval of $\sim 5 \mathrm{Myr}$ (Wignall and Twitchett 2002; Grice et al. 2005; Twitchett 2007; Wignall et al. 2010; Brennecka et al. 2011; Song et al. 2012, 2019; Tian et al. 2014; Zhang et al. 2018). The development of oceanic anoxia closely coincided with the reduction in foraminiferal size seen in our data (Fig. 9), suggesting a causal link. In addition, our data reveal that the decline of foraminiferal size is significantly greater during the PTB interval than during the GLB interval, consistent with the wider extent and intensity of anoxia during the PTB interval.

2. Global warming, triggered by volcanogenic and thermogenic greenhouse gases from Siberian Traps volcanism and contemporaneous volcanic activity around the Paleotethys Ocean (Renne et al. 1995; Svensen et al. 2004, 2009; Brand et al. 2012; Joachimski et al. 2012; Yin and Song 2013; Majorowicz et al. 2014). Oxygen isotope data from conodont apatite represent tropical sea-surface temperature warming of $\sim 10^{\circ} \mathrm{C}$ during the PTB interval (Joachimski et al. 2012, 2020). This hot climate lasted for much of the Early Triassic (Sun et al. 2012; Romano et al. 2013), and therefore 
temporally coincided with the Lilliput effect experienced by foraminifers (Fig. 9). Rapid warming is a likely driver of the Early Triassic Lilliput effect, and foraminiferal sizes only began to increase once the worst of the Early Triassic heat had abated.

We propose that volcanically induced global warming and anoxia were the principal drivers of the Lilliput effect in foraminifers across the GLB and the PTB. Our results do not preclude the role of other environmental elements in the size reduction of foraminifers, such as food shortage (Hallam 1965; Hunt and Roy 2006; Twitchett 2007; Zhang et al. 2016; Atkinson et al. 2019), sea-level change (Twitchett et al. 2005; He et al. 2007; Sigurdsen and Hammer 2016; Atkinson et al. 2019), enhanced input of terrestrial materials (He et al. 2007; Algeo and Twitchett 2010; Chu et al. 2015), and oceanic acidification (Kuroyanagi et al. 2009; Song et al. 2011; Sephton et al. 2015). It is likely that many of these factors together contributed to the Lilliput effect of foraminifers and other organisms during these, and other mass extinction events.

\section{Conclusions}

Our study of 20,226 specimens in 464 genera, 98 families, and 9 suborders from 632 publications during the Permian-Triassic intervals has revealed that: (1) A decrease in foraminifer test volume (and by proxy, size) occurred during the two Permian extinction events (the GLE and PTME). (2) The main influence of the GLE was to reduce the test volumes of Fusulinina. Their size reduction was a function of the preferential extinction of taxa exhibiting gigantism, that is, the larger fusulinoidean fusulinids. The ecological impact of the GLE was modest, and this was clearly a less severe crisis than that of the PTME. (3) The PTME resulted in a major reduction in test volumes for all Permian suborders, that is, Fusulinina, Lagenina, Miliolina, and Textulariina. (4) The synergistic effects of volcanically induced global warming and anoxia are likely the ultimate drivers of the Lilliput effect recorded in our database.

\section{Acknowledgments}

We thank Y. Wang for his help in data collection; X. Dai for assistance with analyses; and E. Jia, X. Liu, and S. Jiang for useful discussions. This research was supported by the National Natural Science Foundation of China (41821001, 41622207, 41530104, 41661134047), the State Key R\&D project of China (2016YFA0601100), the Strategic Priority Research Program of the Chinese Academy of Sciences (XDB26000000), and the National Mineral Rock and Fossil Specimens Resource Center, China. D.P.G.B. acknowledges support from the Natural Environment Research Council (grant no. NE/J01799X/1).

\section{Literature Cited}

Aberhan, M., S. Weidemeyer, W. Kiessling, R. A. Scasso, and F. A. Medina. 2007. Faunal evidence for reduced productivity and uncoordinated recovery in Southern Hemisphere CretaceousPaleogene boundary sections. Geology 35:227-230.

Algeo, T. J., and R. J. Twitchett. 2010. Anomalous Early Triassic sediment fluxes due to elevated weathering rates and their biological consequences. Geology 38:1023-1026.

Angilletta, M. J., T. D. Steury, and M. W. Sears. 2004. Temperature, growth rate, and body size in ectotherms: fitting pieces of a lifehistory puzzle. Integrative Comparative Biology 44:498-509.

Armstrong, H. A., and M. D. Brasier. 2004. Foraminifera. Microfossils 15:142-187.

Atkinson, D. 1994. Temperature and organism size: a biological law for ectotherms? Advances in Ecological Research 25:1-58.

Atkinson, D., and R. M. Sibly. 1997. Why are organisms usually bigger in colder environments? Making sense of a life history puzzle. Trends in Ecology and Evolution 12:235-239.

Atkinson, J. W., P. B. Wignall, J. D. Morton, and T. Aze. 2019. Body size changes in bivalves of the family Limidae in the aftermath of the end-Triassic mass extinction: the Brobdingnag effect. Palaeontology 62:561-582.

Barbault, R. 1988. Body size, ecological constraints, and the evolution of life-history strategies. Evolution Biology 22:261-286.

Basov, I. 1979. Ecology of benthic foraminifera in the upwelling zone near south-west Africa. Voporsy Mikropaleontologii 22:135-146.

Beerling, D. J., M. Harfoot, B. Lomax, and J. A. Pyle. 2007. The stability of the stratospheric ozone layer during the end-Permian eruption of the Siberian Traps. Philosophical Transactions of the Royal Society of London A 365:1843-1866.

Benton, M. J. 2003. When life nearly died: the greatest mass extinction of all time. Cambridge University Press, Cambridge.

Benton, M. J., V. P. Tverdokhlebov, and M. Surkov. 2004. Ecosystem remodelling among vertebrates at the Permian-Triassic boundary in Russia. Nature 432:97-100.

Bjørklund, K. R. 1976. Actinomma haysi, n. sp., its Holocene distribution and size variation in Atlantic Ocean sediments. Micropaleontology 23:114-126.

Black, B. A., J. F. Lamarque, C. A. Shields, L. T. Elkins Tanton, and J. T. Kiehl. 2014. Acid rain and ozone depletion from pulsed Siberian Traps magmatism. Geology 42:67-70.

Blackburn, T. M., and K. J. Gaston. 1994. Animal body size distributions: patterns, mechanisms and implications. Trends in Ecology and Evolution 9:471-474 
Bond, D., P. Wignall, W. Wang, G. Izon, H. S. Jiang, X. L. Lai, Y. D. Sun, R. Newton, L. Y. Shao, and S. Védrine. 2010a. The midCapitanian (Middle Permian) mass extinction and carbon isotope record of south China. Palaeogeography, Palaeoclimatology, Palaeoecology 292:282-294.

Bond, D., P. Wignall, M. Joachimski, Y. Sun, I. P. Savov, S. Grasby, B. Beauchamp, and D. Blomeier. 2015. An abrupt extinction in the Middle Permian (Capitanian) of the Boreal Realm (Spitsbergen) and its link to anoxia and acidification. Geological Society of America Bulletin 127:1411-1421.

Bond, D., S. Grasby, and P. Wignall. 2017. Anoxia, toxic metals and acidification: volcanically-driven causes of the Middle Permian (Capitanian) mass extinction in NW Pangaea? P. 2200 In 19th EGU General Assembly, EGU2017, proceedings from the conference held 23-28 April, 2017 in Vienna, Austria.

Bond, D. P., and S. E. Grasby. 2017. On the causes of mass extinctions. Palaeogeography, Palaeoclimatology, Palaeoecology 478:3-29.

Bond, D. P., and P. B. Wignall. 2010. Pyrite framboid study of marine Permian-Triassic boundary sections: a complex anoxic event and its relationship to contemporaneous mass extinction. Geological Society of America Bulletin 122:1265-1279.

Bond, D. P., P. B. Wignall, and S. E. Grasby. 2020. The Capitanian (Guadalupian, Middle Permian) mass extinction in NW Pangea (Borup Fiord, Arctic Canada): a global crisis driven by volcanism and anoxia. Geological Society of America Bulletin 132:931-942.

Bond, D. P. G., J. Hilton, P. B. Wignall, J. R. Ali, L. G. Stevens, Y. Sun, and X. Lai. 2010b. The Middle Permian (Capitanian) mass extinction on land and in the oceans. Earth Science Reviews 102:100-116.

Borths, M. R., and W. Ausich. 2011. Ordovician-Silurian Lilliput crinoids during the end-Ordovician biotic crisis. Journal of Palaeontology 130:7-18.

Bottjer, D. J., M. E. Clapham, M. L. Fraiser, and C. M. Powers. 2008. Understanding mechanisms for the end-Permian mass extinction and the protracted Early Triassic aftermath and recovery. GSA Today 18:4-10.

Brand, U., R. Posenato, R. Came, H. Affek, L. Angiolini, K. Azmy, and E. Farabegoli. 2012. The end-Permian mass extinction: a rapid volcanic $\mathrm{CO}_{2}$ and $\mathrm{CH}_{4}$-climatic catastrophe. Chemical Geology 322:121-144.

Brayard, A., A. Nützel, D. A. Stephen, K. G. Bylund, J. Jenks, and H. Bucher. 2010. Gastropod evidence against the Early Triassic Lilliput effect. Geology 38:147-150.

Brayard, A., M. Meier, G. Escarguel, E. Fara, A. Nuetzel, N. Olivier, K. G. Bylund, J. F. Jenks, D. A. Stephen, and M. Hautmann. 2015. Early Triassic Gulliver gastropods: spatio-temporal distribution and significance for biotic recovery after the end-Permian mass extinction. Earth-Science Reviews 146:31-64.

Brennecka, G. A., A. D. Herrmann, T. J. Algeo, and A. D. Anbar. 2011. Rapid expansion of oceanic anoxia immediately before the end-Permian mass extinction. Proceedings of the National Academy of Sciences USA 108:17631-17634.

Brown, J. H. 1995. Macroecology. University of Chicago Press, Chicago.

Calder, W. A. 1996. Size, function, and life history. Courier Corporation. Mineola, N.Y.

Cao, Y., H. Song, T. J. Algeo, D. Chu, Y. Du, L. Tian, Y. Wang, and J. Tong. 2019. Intensified chemical weathering during the PermianTriassic transition recorded in terrestrial and marine successions. Palaeogeography, Palaeoclimatology, Palaeoecology 519:166-177.

Chen, B., M. M. Joachimski, Y. Sun, S. Shen, and X. Lai. 2011. Carbon and conodont apatite oxygen isotope records of Guadalupian-Lopingian boundary sections: climatic or sea-level signal? Palaeogeography Palaeoclimatology Palaeoecology 311:145-153.

Chen, B., M. M. Joachimski, S. Shen, L. L. Lambert, X. Lai, X. Wang, J. Chen, and D. Yuan. 2013. Permian ice volume and palaeoclimate history: Oxygen isotope proxies revisited. Gondwana Research 24:77-89.
Chen, J., H. Song, W. He, J. Tong, F. Wang, and S. Wu. 2019. Size variation of brachiopods from the Late Permian through the Middle Triassic in south China: evidence for the Lilliput effect following the Permian-Triassic extinction. Palaeogeography, Palaeoclimatology, Palaeoecology 519:248-257.

Chu, D., J. Tong, H. Song, M. J. Benton, H. Song, J. Yu, X. Qiu, Y. Huang, and L. Tian. 2015. Lilliput effect in freshwater ostracods during the Permian-Triassic extinction. Palaeogeography, Palaeoclimatology, Palaeoecology 435:38-52.

Clapham, M. E., S. Shen, and D. J. Bottjer. 2009. The double mass extinction revisited: reassessing the severity, selectivity, and causes of the end-Guadalupian biotic crisis (Late Permian). Paleobiology 35:32-50.

Clarkson, M. O., S. A. Kasemann, R. A. Wood, T. M. Lenton, S. J. Daines, S. Richoz, F. Ohnemueller, A. Meixner, S. W. Poulton, and E. T. Tipper. 2015. Ocean acidification and the PermoTriassic mass extinction. Science 348:229-232.

Cohen, K. M., Finney, S. C., Gibbard, P. L., and Fan, J. X. 2018. The ICS international chronostratigraphic chart. https://stratigraphy. org/icschart/ChronostratChart2018-08.pdf.

Cotgreave, P. 1993. The relationship between body size and population abundance in animals. Trends in Ecology and Evolution 8:244-248.

Courtillot, V. E., and P. R. Renne. 2003. On the ages of flood basalt events. Comptes Rendus Geoscience 335:113-140.

Damuth, J. 1991. Of size and abundance. Nature 351:268-269.

Detian, Y., Z. Liqin, and Q. Zhen. 2013. Carbon and sulfur isotopic fluctuations associated with the end-Guadalupian mass extinction in South China. Gondwana Research 24:1276-1282.

Erwin, D. H. 1993. The great Paleozoic crisis: life and death in the Permian. Columbia University Press, New York.

Erwin, D. H. 2015. Extinction: how life on Earth nearly ended 250 million years ago, Updated ed. Princeton University Press, Princeton, N.J.

Flügel, E., and W. Kiessling. 2002. Patterns of Phanerozoic reef crises. In W. Kiessling, E. Fluegel, and J. Golonka, eds. Phanerozoic reef patterns. Society for Sedimentary Geology, Tulsa, Okla. SEPM 72:691-733.

Fraiser, M. L., and D. J. Bottjer. 2004. The non-actualistic Early Triassic gastropod fauna: a case study of the Lower Triassic SinbadLimestone member. Palaios 19:259-275.

Fraiser, M. L., R. J. Twitchett, J. A. Frederickson, B. Metcalfe, and D. J. Bottjer. 2011. Gastropod evidence against the Early Triassic Lilliput effect: comment. Geology 39:e232.

Gingerich, P. 1983. Rates of evolution: effects of time and temporal scaling. Science 222:159-162.

Gradstein, F., J. Ogg, and A. Smith. 2004. A geologic time scale. Cambridge University Press, Cambridge.

Grice, K., C. Cao, G. D. Love, M. E. Böttcher, R. J. Twitchett, E. Grosjean, R. E. Summons, S. C. Turgeon, W. Dunning, and Y. Jin. 2005. Photic zone euxinia during the Permian-Triassic superanoxic event. Science 307:706-709.

Groves, J. R., and Y. Wang. 2013. Timing and size selectivity of the Guadalupian (Middle Permian) fusulinoidean extinction. Journal of Paleontology 87:183-196.

Groves, J. R., D. Altiner, and R. Rettori. 2005. Extinction, survival, and recovery of lagenide foraminifers in the Permian-Triassic boundary interval, central Taurides, Turkey. Journal of Palaeontology 79:1-39.

Hallam, A. 1965. Environmental causes of stunting in living and fossil marine benthonic invertebrates. Palaeontology 8:132-155.

Hallam, A., and P. B. Wignall. 1997. Mass extinctions and their aftermath. Oxford University, Oxford.

Hammer, Ø., D. A. Harper, and P. D. Ryan. 2001. PAST: paleontological statistics software package for education and data analysis. Palaeontologia Electronica 4:1-9.

Haq, B. U., and S. R. Schutter. 2008. A chronology of Paleozoic sealevel changes. Science 322:64-68. 
Harries, P. J., and P. O. Knorr. 2009. What does the "Lilliput Effect'" mean? Palaeogeography, Palaeoclimatology, Palaeoecology 284:4-10.

Hayami, I. 1997. Size changes of bivalves and a hypothesis about the cause of mass extinction. Fossils 62:24-36.

He, W., G. R. Shi, Q. Feng, M. J. Campi, S. Gu, J. Bu, Y. Peng, and Y. Meng. 2007. Brachiopod miniaturization and its possible causes during the Permian-Triassic crisis in deep water environments, south China. Palaeogeography Palaeoclimatology Palaeoecology 252:0-163.

He, W., G. R. Shi, R. J. Twitchett, Y. Zhang, K. Zhang, H. Song, M. Yue, S. Wu, H. Wu, T. Yang, and Y. Xiao. 2015. Late Permian marine ecosystem collapse began in deeper waters: evidence from brachiopod diversity and body size changes. Geobiology 13:123-138.

Hinojosa, J. L., S. T. Brown, J. Chen, D. J. DePaolo, A. Paytan, S. Z. Shen, and J. L. Payne. 2012. Evidence for end-Permian ocean acidification from calcium isotopes in biogenic apatite. Geology 40:743-746

Huang, B., D. A. Harper, R. Zhan, and J. Rong. 2010. Can the Lilliput effect be detected in the brachiopod faunas of south China following the terminal Ordovician mass extinction? Palaeogeography Palaeoclimatology Palaeoecology 285:277-286.

Huang, Y., Z.-Q. Chen, T. J. Algeo, L. Zhao, A. Baud, G. M. Bhat, L. Zhang, and Z. Guo. 2019. Two-stage marine anoxia and biotic response during the Permian-Triassic transition in Kashmir, northern India: pyrite framboid evidence. Global and Planetary Change 172:124-139.

Hunt, G., and K. Roy. 2006. Climate change, body size evolution, and Cope's rule in deep-sea ostracodes. Proceedings of the National Academy of Sciences USA 103:1347-1352.

Huttenlocker, A. K. 2014. Body size reductions in nonmammalian eutheriodont therapsids (Synapsida) during the end-Permian mass extinction. PLoS ONE 9:e87553.

Isozaki, Y. 1997. Permo-Triassic boundary superanoxia and stratified superocean: records from lost deep sea. Science 276:235-238

Isozaki, Y., and D. Aljinović. 2009. End-Guadalupian extinction of the Permian gigantic bivalve Alatoconchidae: end of gigantism in tropical seas by cooling. Palaeogeography, Palaeoclimatology, Palaeoecology 284:11-21.

Isozaki, Y., H. Kawahata, A. J. G. Ota, and P. Change. 2007. A unique carbon isotope record across the Guadalupian-Lopingian (Middle-Upper Permian) boundary in mid-oceanic paleo-atoll carbonates: the high-productivity "Kamura event" and its collapse in Panthalassa. Global and Planetary Change 55:21-38.

Jablonski, D. 1986. Causes and consequences of mass extinctions: a comparative approach. Pp. 183-229 in D.K. Elliott, ed. Dynamics of extinction. Wiley, New York.

Jablonski, D. 1996. Body size and macroevolution. Pp. 256-289 in Jablonski, D., D. Erwin, and J. Lipps, eds. Evolutionary paleobiology. University of Chicago Press, Chicago.

Jeffery, C. H., and R. B. Emlet. 2010. Macroevolutionary consequences of developmental mode in temnopleurid echinoids from the tertiary of southern Australia. International Journal of Organic Evolution 57:1031-1048.

Jin, Y., J. Zhang, and Q. Shang. 1994. Two phases of the endPermian mass extinction. Applied Spectroscopy:1707-1711.

Jin, Y., J. Zhang, and Q. Shang. 1995. Pre-Lopingian catastrophic event of marine faunas. Acta Palaeontologica Sinica 4:410-427.

Jin, Y., Y. Wang, W. Wang, Q. Shang, C. Cao, and D. Erwin. 2000. Pattern of marine mass extinction near the Permian-Triassic boundary in south China. Science 289:432-436.

Joachimski, M. M., X. Lai, S. Shen, H. Jiang, G. Luo, B. Chen, J. Chen, and Y. Sun. 2012. Climate warming in the latest Permian and the Permian-Triassic mass extinction. Geology 40:195-198.
Joachimski, M., A. Alekseev, A. Grigoryan, and Y. A. Gatovsky. 2020. Siberian Trap volcanism, global warming and the Permian-Triassic mass extinction: new insights from Armenian Permian-Triassic sections. Geological Society of America Bulletin 132:427-443.

Kaljo, D. 1996. Diachronous recovery patterns in Early Silurian corals, graptolites and acritarchs. Geological Society of London Special Publication 102:127-133.

Kani, T., M. Fukui, Y. Isozaki, and S. Nohda. 2008. The Paleozoic minimum of ${ }^{87} \mathrm{Sr} /{ }^{86} \mathrm{Sr}$ ratio in the Capitanian (Permian) midoceanic carbonates: a critical turning point in the late Paleozoic. Journal of Asian Earth Sciences 32:22-33.

Kidder, D. L., and T. R. Worsley. 2004. Causes and consequences of extreme Permo-Triassic warming to globally equable climate and relation to the Permo-Triassic extinction and recovery. Palaeogeography, Palaeoclimatology, Palaeoecology 203:207-237.

Kiessling, W., E. Kustatscher, N. Preto, and P. Wignall. 2010. Reef expansion during the Triassic: spread of photosymbiosis balancing climatic cooling. Palaeogeography Palaeoclimatology Palaeoecology 290:11-19.

Knoll, A. H., R. Bambach, D. E. Canfield, and J. P. Grotzinger. 1996. Comparative Earth history and Late Permian mass extinction. Science 273:452-457.

Knoll, A. H., R. K. Bambach, J. L. Payne, S. Pruss, and W. W. Fischer. 2007. Paleophysiology and end-Permian mass extinction. Earth and Planetary Science Letters 256:295-313.

Korte, C., T. Jasper, H. W. Kozur, and J. Veizer. $2006 .{ }^{87} \mathrm{Sr} /{ }^{86} \mathrm{Sr}$ record of Permian seawater. Palaeogeography, Palaeoclimatology, Palaeoecology 240:89-107.

Kump, L. R., A. Pavlov, and M. A. Arthur. 2005. Massive release of hydrogen sulfide to the surface ocean and atmosphere during intervals of oceanic anoxia. Geology 33:397-400.

Kuroyanagi, A., H. Kawahata, A. Suzuki, K. Fujita, and T. Irie. 2009. Impacts of ocean acidification on large benthic foraminifers: Results from laboratory experiments. Marine Micropaleontology 73:190-195.

Lau, K. V., K. Maher, D. Altiner, B. M. Kelley, L. R. Kump, D. J. Lehrmann, J. C. Silva-Tamayo, K. L. Weaver, M. Yu, and J. L. Payne. 2016. Marine anoxia and delayed Earth system recovery after the end-Permian extinction. Proceedings of the National Academy of Sciences USA 113:2360-2365.

Lewis, K., and C. Jenkins. 1969. Geographical variation of Nonionellina flemingi. Micropaleontology 15:1-12.

Li, M., H. Song, T. J. Algeo, P. B. Wignall, X. Dai, and A. D. Woods. 2018. A dolomitization event at the oceanic chemocline during the Permian-Triassic transition. Geology 46:1043-1046.

Liang, H. 2002. End-Permian catastrophic event of marine acidification by hydrated sulfuric acid: mineralogical evidence from Meishan Section of south China. Chinese Science Bulletin 47:1393-1397.

Luo, G., X. Lai, G. Shi, H. Jiang, H. Yin, S. Xie, J. Tong, K. Zhang, W. He, and P. B. Wignall. 2008. Size variation of conodont elements of the Hindeodus-Isarcicella clade during the Permian-Triassic transition in south China and its implication for mass extinction. Palaeogeography, Palaeoclimatology, Palaeoecology 264:176-187.

Majorowicz, J., S. Grasby, J. Safanda, and B. Beauchamp. 2014. Gas hydrate contribution to Late Permian global warming. Earth and Planetary Science Letters 393:243-253.

McGowan, A., A. Smith, and P. Taylor. 2009. Faunal diversity, heterogeneity and body size in the Early Triassic: testing postextinction paradigms in the Virgin Limestone of Utah, USA. Australian Journal of Earth Sciences 56:859-872.

Mikhalevich, V. 2000. The phylum Foraminifera d'Orbigny, 1826 Foraminifery. Pp. 533-623 in A. F. Alimov, ed. Protisty: Rukovodstvo po Zoologii. Nauka Publishers, Moscow.

Mutter, R. J., and A. G. Neuman. 2009. Recovery from the endPermian extinction event: evidence from "Lilliput Listracanthus". Palaeogeography, Palaeoclimatology, Palaeoecology 284:22-28. 
Ota, A., and Y. Isozaki. 2006. Fusuline biotic turnover across the Guadalupian-Lopingian (Middle-Upper Permian) boundary in mid-oceanic carbonate buildups: biostratigraphy of accreted limestone in Japan. Journal of Asian Earth Sciences 26:353-368.

Payne, J. L. 2005. Evolutionary dynamics of gastropod size across the end-Permian extinction and through the Triassic recovery interval. Paleobiology 31:269-290.

Payne, J. L., A. G. Boyer, J. H. Brown, S. Finnegan, M. Kowalewski, R. A. Krause, S. K. Lyons, C. R. McClain, D. W. McShea, and P. M. Novack-Gottshall. 2009. Two-phase increase in the maximum size of life over 3.5 billion years reflects biological innovation and environmental opportunity. Proceedings of the National Academy of Sciences USA 106:24-27.

Payne, J. L., M. Summers, B. L. Rego, D. Altiner, J. Wei, M. Yu, and D. J. Lehrmann. 2011. Early and Middle Triassic trends in diversity, evenness, and size of foraminifers on a carbonate platform in south China: implications for tempo and mode of biotic recovery from the end-Permian mass extinction. Paleobiology 37:409-425.

Payne, J. L., J. R. Groves, A. B. Jost, T. Nguyen, S. E. Moffitt, T. M. Hill, and J. M. Skotheim. 2012. Late Paleozoic fusulinoidean gigantism driven by atmospheric hyperoxia. Evolution: International Journal of Organic Evolution 66:2929-2939.

Payne, J. L., A. B. Jost, S. C. Wang, and J. M. Skotheim. 2013. A shift in the long-term mood of foraminiferan size evolution cause by the end-Permian mass extinction. Evolution: International Journal of Organic Evolution 67:816-827.

Penn, J. L., C. Deutsch, J. L. Payne, and E. A. Sperling. 2018. Temperature-dependent hypoxia explains biogeography and severity of end-Permian marine mass extinction. Science 362: eaat1327.

Petchey, O. L., and A. Belgrano. 2010. Body-size distributions and size-spectra: universal indicators of ecological status? Biology Letters 6:434-437.

Peters, P. 1983. The ecological implication of body size. Cambridge University Press, Cambridge.

Posenato, R. 2009. Survival patterns of macrobenthic marine assemblages during the end-Permian mass extinction in the western Tethys (Dolomites, Italy). Palaeogeography, Palaeoclimatology, Palaeoecology 280:150-167.

Racki, G., and P. B. Wignall. 2005. Late Permian double-phased mass extinction and volcanism: an oceanographic perspective. Developments in Palaeontology and Stratigraphy 20:263-297.

Raup, D. M. 1975. Taxonomic diversity estimation using rarefaction. Paleobiology 1:333-342.

Raup, D. M. 1979. Size of the Permo-Triassic bottleneck and its evolutionary implications. Science 206:217-218.

Rego, B. L., S. C. Wang, D. Altiner, and J. L. Payne. 2012. Within- and among-genus components of size evolution during mass extinction, recovery, and background intervals: a case study of Late Permian through Late Triassic foraminifera. Paleobiology 38:627-643.

Reichow, M. K., M. Pringle, A. Al'Mukhamedov, M. Allen, V. Andreichev, M. Buslov, C. Davies, G. Fedoseev, J. Fitton, and S. Inger. 2009. The timing and extent of the eruption of the Siberian Traps large igneous province: Implications for the endPermian environmental crisis. Earth and Planetary Science Letters 277:9-20.

Renaud, S., and C. Girard. 1999. Strategies of survival during extreme environmental perturbations: evolution of conodonts in response to the Kellwasser crisis (Upper Devonian). Palaeogeography Palaeoclimatology Palaeoecology 146:19-32.

Renne, P. R., M. T. Black, Z. Zichao, M. A. Richards, and A. R. Basu. 1995. Synchrony and causal relations between Permian-Triassic boundary crises and Siberian flood volcanism. Science 269:1413-1416.

Retallack, G. J. 2002. Lepidopteris callipteroides, an earliest Triassic seed fern of the Sydney Basin, southeastern Australia. Alcheringa 26:475-500.
Retallack, G. J. 2005. Permian greenhouse crises. The nonmarine Permian. New Mexico Museum of Natural History Science Bulletin 30:256-269.

Rhoads, D. C., and J. W. Morse. 1971. Evolutionary and ecologic significance of oxygen-deficient marine basins. Lethaia 4:413-428.

Romano, C., N. Goudemand, T. W. Vennemann, D. Ware, E. Schneebelihermann, P. A. Hochuli, T. Brühwiler, W. Brinkmann, and H. Bucher. 2013. Climatic and biotic upheavals following the end-Permian mass extinction. Nature Geoscience 6:57-60.

Ross, C. A. 1972. Paleobiological analysis of fusulinacean (Foraminiferida) shell morphology. Journal of Paleontology:719-728.

Sanders, H. L. 1968. Marine benthic diversity: a comparative study. American Naturalist 102:243-282.

Sanei, H., S. E. Grasby, and B. Beauchamp. 2012. Latest Permian mercury anomalies. Geology 40:63-66.

Schaal, E. K., M. E. Clapham, B. L. Rego, S. C. Wang, and J. L. Payne. 2016. Comparative size evolution of marine clades from the Late Permian through Middle Triassic. Paleobiology 42:127-142.

Schmidt, D. N., H. R. Thierstein, and J. Bollmann. 2004. The evolutionary history of size variation of planktic foraminiferal assemblages in the Cenozoic. Palaeogeography, Palaeoclimatology, Palaeoecology 212:159-180.

Schmidt, D. N., D. Lazarus, J. R. Young, and M. Kucera. 2006. Biogeography and evolution of body size in marine plankton. EarthScience Reviews 78:239-266.

Schmidt-Nielsen, K. 1984. Scaling, why is animal size so important? Cambridge University Press, Cambridge

Schubert, J. K., and D. J. Bottjer. 1995. Aftermath of the PermianTriassic mass extinction event: paleoecology of Lower Triassic carbonates in the western USA. Palaeogeography, Palaeoclimatology, Palaeoecology 116:1-39.

Sephton, M. A., D. Jiao, M. H. Engel, C. V. Looy, and H. Visscher. 2015. Terrestrial acidification during the end-Permian biosphere crisis? Geology 43:159-162.

Sepkoski, J. J., Jr., R. K. Bambach, D. M. Raup, and J. W. Valentine. 1981. Phanerozoic marine diversity and the fossil record. Nature 293:435-437.

Shen, S. Z., and G. Shi. 2009. Latest Guadalupian brachiopods from the Guadalupian/Lopingian boundary GSSP section at Penglai$\tan$ in Laibin, Guangxi, South China and implications for the timing of the pre-Lopingian crisis. Palaeoworld 18:152-161.

Shen, W., Y. Lin, L. Xu, J. Li, Y. Wu, and Y. Sun. 2007. Pyrite framboids in the Permian-Triassic boundary section at Meishan, China: evidence for dysoxic deposition. Palaeogeography, Palaeoclimatology, Palaeoecology 253:323-331.

Sigurdsen, A., and O. Hammer. 2016. Body size trends in the Ordovician to earliest Silurian of the Oslo Region. Palaeogeography, Palaeoclimatology, Palaeoecology 443:49-56.

Smith, F. A., J. L. Betancourt, and J. H. Brown. 1995. Evolution of body size in the woodrat over the past 25,000 years of climate change. Science 270:2012-2014.

Song, H., and J. Tong. 2010. Size variation of foraminifers during the Permian-Triassic transition at Meishan Section, south China. Journal of Earth Science 21:154-157.

Song, H., J. Tong, and Z. Chen. 2011. Evolutionary dynamics of the Permian-Triassic foraminifer size: evidence for Lilliput effect in the end-Permian mass extinction and its aftermath. Palaeogeography, Palaeoclimatology, Palaeoecology 308:98-110.

Song, H., P. B. Wignall, J. Tong, D. P. Bond, H. Song, X. Lai, K. Zhang, H. Wang, and Y. Chen. 2012. Geochemical evidence from bio-apatite for multiple oceanic anoxic events during Permian-Triassic transition and the link with end-Permian extinction and recovery. Earth and Planetary Science Letters 353:12-21.

Song, H., P. B. Wignall, J. Tong, and H. Yin. 2013. Two pulses of extinction during the Permian-Triassic crisis. Nature Geoscience 6:52. 
Song, H., P. B. Wignall, and A. M. Dunhill. 2018. Decoupled taxonomic and ecological recoveries from the Permo-Triassic extinction. Science Advances 4:5091.

Song, H., P. B. Wignall, H. Song, X. Dai, and D. Chu. 2019. Seawater temperature and dissolved oxygen over the past 500 million years. Journal of Earth Science 30:236-243.

Song, H., S. Huang, E. Jia, X. Dai, P. B. Wignall, and A. M. Dunhill. 2020. Flat latitudinal diversity gradient caused by the PermianTriassic mass extinction. Proceedings of the National Academy of Sciences USA 117:17578-17583.

Stanley, S. M., and X. Yang. 1994. A double mass extinction at the end of the Paleozoic Era. Science 266:1340-1344.

Sun, Y., M. M. Joachimski, P. B. Wignall, C. Yan, Y. Chen, H. Jiang, L. Wang, and X. Lai. 2012. Lethally hot temperatures during the Early Triassic greenhouse. Science 338:366-370.

Svensen, H., S. Planke, A. Malthe-Sørenssen, B. Jamtveit, R. Myklebust, T. R. Eidem, and S. S. Rey. 2004. Release of methane from a volcanic basin as a mechanism for initial Eocene global warming. Nature 429:542-545.

Svensen, H., S. Planke, A. G. Polozov, N. Schmidbauer, F. Corfu, Y. Y. Podladchikov, and B. J. E. Jamtveit. 2009. Siberian gas venting and the end-Permian environmental crisis. Earth and Planetary Science Letters 277:490-500.

Tappan, H., and A. R. Loeblich Jr. 1988. Foraminiferal evolution, diversification, and extinction. Journal of Palaeontology 62:695-714

Tian, L., J. Tong, T. J. Algeo, H. Song, H. Song, D. Chu, S. Lei, and D. J. Bottjer. 2014. Reconstruction of Early Triassic ocean redox conditions based on framboidal pyrite from the Nanpanjiang Basin, south China. Palaeogeography, Palaeoclimatology, Palaeoecology 412:68-79.

Twitchett, R. J. 2007. The Lilliput effect in the aftermath of the endPermian extinction event. Palaeogeography, Palaeoclimatology, Palaeoecology 252:132-144.

Twitchett, R. J., J. M. Feinberg, D. D. O'Connor, W. Alvarez, and L. B. McCollum. 2005. Early Triassic ophiuroids: their paleoecology, taphonomy, and distribution. Palaios 20:213-223.

Urbanek, A. 1993. Biotic crises in the history of Upper Silurian graptoloids: a palaeobiological model. Historical Biology 7:29-50.

Veizer, J., D. Ala, K. Azmy, P. Bruckschen, D. Buhl, F. Bruhm, G. Carden, A. Diener, S. Ebneth, and Y. Godderis. 1999. ${ }^{87 \mathrm{Sr} / 86} \mathrm{Sr}, \delta^{13} \mathrm{C}$ and $\delta^{18} \mathrm{O}$ evolution of Phanerozoic seawater. Chemical Geology 161:59-88.

Visscher, H., C. V. Looy, M. E. Collinson, H. Brinkhuis, J. H. Van Konijnenburg-Van Cittert, W. M. Kürschner, and M. A. Sephton. 2004. Environmental mutagenesis during the endPermian ecological crisis. Proceedings of the National Academy of Sciences USA 101:12952-12956.
Wang, C. 2007. Anomalous hopane distributions at the PermianTriassic boundary, Meishan, China-evidence for the endPermian marine ecosystem collapse. Organic Geochemistry 38:52-66.

Wang, X. D., and T. Sugiyama. 2000. Diversity and extinction patterns of Permian coral faunas of China. Lethaia 33:285-294.

Wignall, P., and A. Hallam. 1992. Anoxia as a cause of the Permian/Triassic mass extinction: facies evidence from northern Italy and the western United States. Palaeogeography, Palaeoclimatology, Palaeoecology 93:21-46.

Wignall, P. B. 2001. Large igneous provinces and mass extinctions. Earth-Science Reviews 53:1-33.

Wignall, P. B., and R. J. Twitchett. 1996. Oceanic anoxia and the end Permian mass extinction. Science 272:1155-1158.

Wignall, P. B., and R. J. Twitchett. 2002. Extent, duration, and nature of the Permian-Triassic superanoxic event. Geological Society of America Special Paper 356:395-414.

Wignall, P. B., Y. Sun, D. P. Bond, G. Izon, R. J. Newton, S. Védrine, M. Widdowson, J. R. Ali, X. Lai, and H. Jiang. 2009. Volcanism, mass extinction, and carbon isotope fluctuations in the Middle Permian of China. Science 324:1179-1182.

Wignall, P. B., D. P. Bond, K. Kuwahara, Y. Kakuwa, R. J. Newton, and S. W. Poulton. 2010. An 80 million year oceanic redox history from Permian to Jurassic pelagic sediments of the Mino-Tamba terrane, SW Japan, and the origin of four mass extinctions. Global and Planetary Change 71:109-123.

Yang, X., L. Jiarun, and S. Guijun. 2004. Extinction process and patterns of Middle Permian fusulinaceans in southwest China. Lethaia 37:139-147.

Yin, H., and H. Song. 2013. Mass extinction and Pangea integration during the Paleozoic-Mesozoic transition. Science China Earth Sciences 56:1791-1803.

Zhang, F., T. J. Algeo, S. J. Romaniello, Y. Cui, L. Zhao, Z.-Q. Chen, and A. D. Anbar. 2018. Congruent Permian-Triassic $\delta^{238} U$ records at Panthalassic and Tethyan sites: confirmation of global-oceanic anoxia and validation of the U-isotope paleoredox proxy. Geology 46:327-330.

Zhang, Y., and J. L. Payne. 2012. Size-frequency distributions along a latitudinal gradient in Middle Permian fusulinoideans. PLoS ONE 7:38603.

Zhang, Y., G. Shi, W. H. He, H. T. Wu, Y. Lei, K. X. Zhang, C. C. Du, T. L. Yang, M. L. Yue, and Y. F. Xiao. 2016. Significant pre-mass extinction animal body-size changes: evidences from the Permian-Triassic boundary brachiopod faunas of south China. Palaeogeography, Palaeoclimatology, Palaeoecology 448:85-95.

Zhang, Z., M. Augustin, and J. L. Payne. 2015. Phanerozoic trends in brachiopod body size from synoptic data. Paleobiology 41:491-501. 